\title{
Growth and diel vertical migration patterns of the toxic dinoflagellate Protoceratium reticulatum in a water column with salinity stratification: the role of bioconvection and light
}

\author{
Svein Rune Erga*, Christine Daae Olseng, Lars Harald Aarø \\ Department of Biology, University of Bergen, PO Box 7803, 5020 Bergen, Norway
}

\begin{abstract}
Novel data on growth and migratory behaviour of a southern Norwegian strain of Protoceratium reticulatum (Dinophyceae) were obtained from long-lasting (14-22 d) experiments in a water column with salinity gradient $(\Delta \mathrm{S}=4$ [30-34 psu] and 14 [20-34 psu]), light intensity of $100 \mu \mathrm{mol}$ photons $\mathrm{m}^{-2} \mathrm{~s}^{-1}$ and light:dark cycle of 14:10 h. Based on specific growth experiments (maximum growth rate: 0.3 divisions $\mathrm{d}^{-1}$ ), these environmental conditions were considered near optimal. Upward migration at an average speed of $0.6 \mathrm{~m} \mathrm{~h}^{-1}$ (maximum $4.0 \mathrm{~m} \mathrm{~h}^{-1}$ ) was controlled by positive phototaxis. Ascending populations managed to pass the halocline after an osmotic adjustment time of 4 and $8 \mathrm{~d}$ in the case of $\Delta \mathrm{S}=4$ and 14, respectively, and once this was achieved the vertical migration cycle was restricted to the upper layer. Descent from the surface started once the dark period was initiated. Very slow sinking speeds $\left(0.03-0.08 \mathrm{~m} \mathrm{~h}^{-1}\right)$ during darkness resulted in a random distribution of algal cells within the upper layer, indicating a balance between negative and positive geotaxis. After about $1 \mathrm{wk}$, bioconvection (i.e. pattern-forming motions caused by hydrodynamic instabilities in suspensions of swimming microalgae) became an important part of the migration pattern during the day. Dense surface patches of cells were formed after $1-2 \mathrm{~h}$ in the light, followed by fast-sinking $\left(5 \mathrm{~m} \mathrm{~h}^{-1}\right)$ plumes/droplets extending down to the halocline. This motion pattern lasted for the rest of the light period, being repeated for several light cycles. Despite nitrate limitation in the upper layer, $P$. reticulatum did not migrate down below the halocline where nutrients were sufficient.
\end{abstract}

KEY WORDS: Vertical migration · Dinoflagellate $\cdot$ Growth $\cdot$ Halocline $\cdot$ Light $\cdot$ Diel patterns Nutrients $\cdot$ Bioconvection $\cdot$ Phototaxis

\section{INTRODUCTION}

Dinoflagellates are well known for forming harmful algal blooms (HABs/red tides; Smayda 1997, Smayda \& Reynolds 2001), and they are considered to be among the best swimmers among flagellated algae, many with swimming/sinking speeds of 200 to $600 \mathrm{\mu m} \mathrm{s}^{-1}$ (0.7-1.8 $\mathrm{m} \mathrm{h}^{-1}$; Smayda 2002). Diel vertical migration (DVM) have been described for many dinoflagellate species both in nature (Hasle 1950,

\footnotetext{
*Corresponding author: svein.erga@uib.no
}

Eppley et al. 1968, Blasco 1978, Park et al. 2001, Fauchot et al. 2005) and from laboratory studies in experimental water columns (Cullen \& Horrigan 1981, Olsson \& Granéli 1991, MacIntyre et al. 1997, Jephson \& Carlsson 2009, Jephson et al. 2011). The DVM pattern for a given species is often a result of physiological and behavioural adaptations, strongly influenced by environmental parameters like light (Blasco 1978, Eggersdorfer \& Häder 1991, Passow 1991, Park et al. 2001), nutrients and temperature (Kamykowski \&

() The authors 2015. Open Access under Creative Commons by Attribution Licence. Use, distribution and reproduction are unrestricted. Authors and original publication must be credited. 
Zentara 1977, Blasco 1978, Cullen \& Horrigan 1981, MacIntyre et al. 1997, John \& Flynn 2000) and salinity (Rasmussen \& Richardson 1989, Jephson et al. 2011). Although there are differences in migration patterns between species, the most pronounced pattern is surface aggregation during light periods and sub-surface dispersal or aggregations during the dark period (Heaney \& Talling 1980, Cullen \& Horrigan 1981, Tyler \& Seliger 1981, Kamykowski 1995, Park et al. 2001, Tardio et al. 2005). The ascent is often attributed to a phototactic response to light (positive phototaxis), and the descent in the dark is a response to gravity (positive geotaxis) (Kamykowski \& Yamazaki 1997, Kamykowski et al. 1998, 1999). It is also known that non-pigmented dinoflagellates conduct DVMs driven by positive and negative geotaxis in combination with other environmental factors (Kamykowski 1995).

When grown in the laboratory, swimming microorganisms have for a long time been observed to spontaneously form patterns with cells being typically concentrated into special cell clusters (Wager 1911). Bioconvection and fluid mechanics theory have been applied to explain such phenomena (Pedley \& Kessler 1992, Vincent \& Hill 1996, Ghorai \& Hill 2005, Bearon \& Grünbaum 2006, 2008, Karimi \& Ardekani 2013, Zhan et al. 2014), and gyrotaxis is considered to be the main regulatory mechanism for upwardsswimming cells (Kessler 1985, Mitchell et al. 1990). Bioconvection therefore describes a type of convection set up by density instability at the surface due to dense cell aggregations formed by upwardsswimming microalgae. Important in this context is that gravitational and viscous torque act together with vertical shear forces, leading to self-focussed accumulation of cells and formation of descending plumes with sinking velocities increased by an order of magnitude compared with normal swimming cells (Mitchell et al. 1990, Pedley \& Kessler 1992). Biconvection as a phenomenon has also been observed in calm natural waters (Bearon \& Grünbaum 2006).

In many species, e.g. Lingulodinium polyedrum (= Gonyaulax polyedra) and Gymnodinium splendens, there also seems to be an endogenous component involved in the migration behaviour. This is confirmed by cells starting descent before dark and ascent before the beginning of the light period (Eppley et al. 1968, Heaney \& Eppley 1981, Park et al. 2001). For this to occur in natural populations, however, it is essential that external physical perturbations are small. Following the idea of Hutchinson (1953), changes in the physical regime on time scales longer than the generation time of the organism will prevent competitive exclusion. Even if increased abundances and blooms of dinoflagellates are commonly reported from low-turbulence coastal waters (Thomas \& Gibson 1990, Estrada \& Berdalet 1997), other studies indicate great variance in turbulence sensitivity among dinoflagellates and suggest that they apparently are less sensitive to turbulence than formerly assumed (Smayda 2002, Sullivan \& Swift 2003). The increased occurrence of dinoflagellates in low-turbulence waters is primarily due to reduced physical dispersion, allowing for accumulation of biomass (Gentien et al. 2007). Stratification is among the main factors that reduce vertical water exchange and stabilize vertical mixing (Pingree et al. 1975, Pitcher et al. 1998).

In fjords and coastal areas, stratification occurs due to haloclines (Erga \& Heimdal 1984, Paasche \& Erga 1988, Erga 1989, Erga et al. 2005), and it is often a seasonal event, being highly variable both in magnitude and duration, depending upon freshwater runoff from land (Frette et al. 2004, Aure et al. 2007, Erga et al. 2012). Weise et al. (2002) emphasized the link between precipitation, river runoff and blooms of the toxic dinoflagellate Alexandrium tamaranse in the St. Lawrence, Canada. However, long-lasting stratification often leads to a nutrient-depleted euphotic zone above the pycnocline, conditions claimed to be a competitive advantage for dinoflagellates due to their swimming ability (MacIsaac 1978, Dortch \& Maske 1982, Fauchot et al. 2005, Jephson et al. 2011). By DVM they are able to conduct photosynthesis near the surface during the day and exploit nutrientrich waters below the pycnocline at night (Eppley et al. 1968, Cullen \& Horrigan 1981, Raven \& Richardson 1984, Olsson \& Granéli 1991, Fraga et al. 1992, Villarino et al. 1995). Addressing possible effects of climate change on phytoplankton community structure in the NW Atlantic, Johns et al. (2003) found a drastic change during the 1990s, with the dinoflagellate Ceratium arcticum becoming more and more dominant, probably a result of changes in stratification.

Protoceratium reticulatum (Claparède \& Lachmann) Bütschli (= Gonyaulax grindleyi Reinecke) together with the closely related species $L$. polyedrum and G. spinifera have been shown to be the biogenic origins of yessotoxins (YTXs; Grindley \& Nel 1970, Satake et al. 1997, Draisci et al. 1999, MacKenzie et al. 2002). Since the discovery of this group of disulphated polyether toxins in shellfish from Japan in 1986, the toxin has been reported from shellfish in many other countries, including Norway, New Zealand, Italy and Chile (see Ciminiello et al. 
1997, Aasen et al. 2005). Most of the work done on $P$. reticulatum concern YTX production, its effects and accumulation in shellfish, but rather little on growth and migratory behaviour, which are crucial factors for understanding its bloom dynamics. Such knowledge will also be beneficial for monitoring and for the understanding of food web interactions. Our study aimed to determine the effects of haloclines and light:dark shifts on DVM patterns of a southern Norwegian coastal isolate of $P$. reticulatum. To acquire such data, we performed long-lasting experiments (14-22 d) in an artificial water column equipped with an externally moving optical system (AWCEMOS; see Erga et al. 1999 for further details), which is especially designed to reveal fine-scale vertical distribution of cells. More knowledge on the complex mechanisms regulating the DVMs of many dinoflagellates is crucial for a better prediction of where and when to expect HABs.

\section{MATERIALS AND METHODS}

\section{Cultures and growth experiments}

The Protoceratium reticulatum (Pret01/12 strain, $25 \mu \mathrm{m}$ wide and $27 \mu \mathrm{m}$ long) used in this study was isolated from net hauls taken at a coastal locality outside the city of Mandal, close to the southernmost tip of Norway $\left(57^{\circ} 45.8^{\prime} \mathrm{N}, 7^{\circ} 38.7^{\prime} \mathrm{E}\right)$. After isolation, the culture strain was kept at a temperature of $15^{\circ} \mathrm{C}$, salinity of $30 \mathrm{psu}$, irradiance of $100 \mu \mathrm{mol}$ photons $\mathrm{m}^{-2}$ $\mathrm{s}^{-1}$ and light:dark (LD) cycle of $14: 10 \mathrm{~h}$ prior to the experiments.

Growth of Pret01/12 was studied as an effect of (1) irradiance-photosynthetic active radiation (PAR: 25, 50, 75, 100, 150, 200, $400 \mu \mathrm{mol}$ photons $\mathrm{m}^{-2} \mathrm{~s}^{-1}$ ) at constant temperature $\left(15^{\circ} \mathrm{C}\right)$ and salinity (30 psu); as an effect of (2) temperature $\left(5,10,15,20,25^{\circ} \mathrm{C}\right)$ at constant irradiance $\left(150 \mu \mathrm{mol}\right.$ photons $\left.\mathrm{m}^{-2} \mathrm{~s}^{-1}\right)$ and salinity (30 psu); and as an effect of (3) salinity $(10,15,20,25,30,34 \mathrm{psu})$ at constant irradiance (150 $\mu \mathrm{mol}$ photons $\left.\mathrm{m}^{-2} \mathrm{~s}^{-1}\right)$ and temperature $\left(15^{\circ} \mathrm{C}\right)$. The growth medium used was IMR/2 (Eppley et al. 1967), and all flasks had a surplus of nutrients. All experiments were conducted under an LD cycle of $14: 10 \mathrm{~h}$ in $300 \mathrm{ml}$ Erlenmeyer flasks placed in temperature-controlled water baths. The water baths were illuminated from the side by $540 \mathrm{~W} / 830$ fluorescent light tubes (Philips TL-M Pro). Scalar irradiance was measured inside a water-filled Erlenmeyer flask situated inside the aquarium with a quantum scalar irradiance meter (Spherical sensor, Biospherical In- struments, QSL-100). The irradiance gradient was obtained by wrapping neutral density filters with different transparency around the flasks.

Different salinities were obtained (when necessary) by diluting filtered seawater with distilled water, and the nutrient contents were adjusted to make up for the dilution. Salinity was measured by a conductivity meter (WTW Conductivity Meter LF 538). For each treatment (salinity, irradiance or temperature), triplicate samples of $250 \mathrm{ml}$ were used. Cultures were acclimated to the experimental conditions and kept in exponential growth phase by dilution, except the experiment at $5^{\circ} \mathrm{C}$ which was first kept at $10^{\circ} \mathrm{C}$ to be able to keep them in exponential growth phase. Initial concentration was 1000 cells $\mathrm{ml}^{-1}$ in all experiments, except for the light-tolerance experiment, in which the cell concentration was reduced to 300 cells ml ${ }^{-1}$ to avoid effects of self-shading. Each experiment lasted for 35 to $45 \mathrm{~d}$, and every 2 to $4 \mathrm{~d}$, flasks were gently shaken to ensure homogenous distribution before samples $(5 \mathrm{ml})$ for cell counts were taken. Algae samples were fixed with Lugol's solution (4\% final concentration). After sampling, the positions of the parallel flasks in the aquaria were switched, to account for any possible differences in irradiance. Three times during each experiment (start, middle and end), $10 \mathrm{ml}$ samples were filtered onto GF/C filters $(25 \mathrm{~mm}$ ) for chlorophyll a (chl a) analysis and stored at $-31^{\circ} \mathrm{C}$. The analyses were done fluorometrically (Perkin Elmer luminescence spectrometer-LS 50 B) within 4 wk according to Parsons et al. (1992), using $90 \%$ acetone as a solvent and acid corrections for phaeopigments.

\section{Cell counts and calculations}

Microscopic cell counts on fixed samples were performed under a light microscope (Leica DMRBE or Leica CTR 6000, Leica Microsystems), with a FuchsRosenthal (>3000 cells $\mathrm{ml}^{-1}$ ) or a Palmer-Maloney $\left(<3000\right.$ cells $\left.\mathrm{ml}^{-1}\right)$ counting chamber. Dividing cells were counted as 2 and dead cells were left out. Growth rates $(\mu)$ given as divisions per day $\left(\operatorname{div~} \mathrm{d}^{-1}\right)$ were calculated as follows:

$$
\mu=\ln \left(N_{f} / N_{i}\right) /(\ln 2) t
$$

where $N_{f}$ and $N_{i}$ are the final and initial cell concentration, respectively, and $t$ is the time in days $(24 \mathrm{~h})$. Growth rates were calculated based on a minimum of 4 data points from exponential growth phase using least squares fit of a straight line on log-transformed data. 


\section{Vertical migration experiments}

Fine-scale vertical distribution patterns of $P$. reticulatum due to differences in halocline strength were performed in the AWCEMOS, described by Erga et al. (1999). The system consists of a rectangular 2121 (height $149 \mathrm{~cm}$, width $52.0 \mathrm{~cm}$, depth $27.4 \mathrm{~cm}$ ) Plexiglas column. Downward irradiance is provided by 3 fluorescent light tubes (18 W, Philips TLD/950) placed above the column, giving a surface PAR intensity of $100 \mu \mathrm{mol}$ photons $\mathrm{m}^{-2} \mathrm{~s}^{-1}$. On the outside of the column, an optical detection system consisting of 2 laser diodes (maximum output signal at $670 \mathrm{~nm}$ ), lens system and 2 detectors is mounted on a movable frame. Together with the surface light source (onoff), this movable frame is operated by a computer using the program LabVIEW 6.1 (National Instruments). Laser readings are collected on the way down approximately every $0.24 \mathrm{~cm}(1 \mathrm{~cm}=1.43 \mathrm{l})$. Each run (down-up) is stored as a text file. One run takes about $2 \mathrm{~min}$, which sets the lower limit between runs to $3 \mathrm{~min}$. Since the original description (Erga et al. 1999), several modifications have been made regarding the computer system and installation of 7 syringe valves $(16,28,41,54,67,80$ and $92 \mathrm{~cm}$ from bottom) on the side of the Plexiglas column for sample collection during experiments.

Haloclines were established by carefully filling seawater (gravity fed) with different salinities through an adjustable bottom tap from an elevated container, resulting in an upper 'low salinity' layer and a lower 'high salinity' layer. The bottom tap was connected to an inlet cover inside the tank to spread the inflowing water along the bottom. This, together with a low filling rate $\left(0.1-11 \mathrm{~min}^{-1}\right.$, depending on the distance from the halocline), will reduce the risk of turbulence to a minimum. For further details, see the schematic diagram in Erga et al. (1999). The seawater used in all experiments was taken from $100 \mathrm{~m}$ depth outside the city of Bergen. Typical for this water are temperatures of $5-10^{\circ} \mathrm{C}$, salinity $33-35 \mathrm{psu}$, nitrate values of
10-20 $\mu \mathrm{mol} \mathrm{l}^{-1}$, silicate $10-15 \mu \mathrm{mol} \mathrm{l} \mathrm{l}^{-1}$ and phosphate 0.5-1.0 $\mathrm{mmol} \mathrm{l}^{-1}$ (Erga et al. 2003). The seawater was stored for at least $1 \mathrm{mo}$ in darkness at room temperature $\left(16.7-18.2^{\circ} \mathrm{C}\right)$, and filtered through a filter bag $(1 \mu \mathrm{m}$ mesh size, ARL Filter AB) prior to experiments. To obtain the desired salinity for the upper layer, seawater was diluted to the desired salinity (20-31 psu) with distilled water (see Table 1). The salinity of the lower layer was not diluted (33-34.5 psu).

Four experiments with Pret01/12 were conducted (Table 1). Cultures were grown in batch cultures (non-axenic) at $17^{\circ} \mathrm{C}$ and irradiance of $100 \mu \mathrm{mol}$ photons $\mathrm{m}^{-2} \mathrm{~s}^{-1}$ at an LD of 14:10 $\mathrm{h}$ in the same seawater as used in AWCEMOS, except for an enrichment with IMR/2 nutrients (Eppley et al. 1967). The salinity of the upper layer was 20 or $30 \mathrm{psu}$, and the lower layer was 34 psu (see Table 1). Exponentially growing algae cultures $(7.5$ l) were carefully inserted either into the uppermost $20 \mathrm{l}$ or the lowest $20 \mathrm{l}$ via the bottom tap during the filling of seawater until a final cell density of 1110 to 2200 cells ml ${ }^{-1}$ was reached (Table 1). The seawater used for preconditioning of the inoculum cultures was the same as that used in the water column experiments (i.e. same salinity and temperature), thereby avoiding buoyancy effects due to differences in salinity and temperature. The transfer of the Pret01/12 cultures (growth medium included) to the water column resulted in nutrient levels above those of the natural seawater in the inoculum layer (see Table 3). Due to the strong phototactic response of $P$. reticulatum, the main light source on top of the AWCEMOS was turned off and an additional light source was placed below the water column $(2 \times 18 \mathrm{~W}$ fluorescent light tubes, Philips TLD/950) during filling to keep the cells close to the bottom until the experiments were started. The top light was turned on after the insertion of algae was completed. This routine was followed only in experiments with algal suspensions inserted into the bottom layer (experiments $L S$ and $L s)$. For the 2 experiments with algal suspensions

Table 1. Experimental conditions for Protoceratium reticulatum (Pret01/12 strain) in the artificial water column. Us and US, and $L s$ and $L S$ indicate that the cells were introduced in the upper $(U)$ or lower $(L)$ layer with a weak $(s)$ or strong halocline $(S)$.

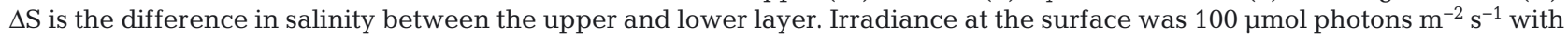
a photoperiod of 14:10 h L:D

\begin{tabular}{|c|c|c|c|c|c|c|}
\hline Experiment & $\begin{array}{l}\text { Duration } \\
\text { (d) }\end{array}$ & $\begin{array}{c}\text { Temperature } \\
\left({ }^{\circ} \mathrm{C}\right)\end{array}$ & $\begin{array}{l}\text { Salinity } \\
\text { (psu) } U: L\end{array}$ & $\begin{array}{c}\Delta \mathrm{S} \\
\text { (halocline) }\end{array}$ & $\begin{array}{l}\text { Volume } \\
\text { (l) } U: L\end{array}$ & $\begin{array}{l}\text { Initial concentration } \\
\left.(\text { cells ml })^{-1}\right)\end{array}$ \\
\hline US & 18 & 18.2 & 19.9:33.8 & 13.9 & 59.1:97.2 & 2205 \\
\hline$U_{S}$ & 22 & 18.0 & $30: 34.5$ & 4.5 & $58.4: 98.3$ & 1107 \\
\hline$L S$ & 14 & 20.0 & $20: 34.1$ & 14.1 & 59.1:97.2 & 2186 \\
\hline$L s$ & 22 & 17.8 & 29.8:34.1 & 4.3 & 58.0:96.6 & 1354 \\
\hline
\end{tabular}


inserted into the upper layer (experiments $U S$ and $U s)$, the main light source on top was on during filling to keep the cells close to surface. All experiments were done under LD of 14:10 h.

The following abbreviations were used to describe the experimental conditions: $U S=$ Pret01/12 initially in the upper layer with a strong halocline $(\Delta \mathrm{S}=$ $14 \mathrm{psu}), U_{s}=$ Pret01/12 initially in the upper layer with a weak halocline $(\Delta \mathrm{S}=4 \mathrm{psu}), L S=$ Pret01/12 initially in the bottom layer with a strong halocline, and $L s=$ Pret01/12 initially in the bottom layer with a weak halocline.

Salinity and temperature profiles of the water column were obtained by using a Conductivity Meter LF 538 coupled to a Tetracon 325 sensor system (both produced by Wissenschaftlich-Technische Werkstätten) at the beginning and the end of the experiments. The initial measurements were conducted on the inflowing water before entering the water column, to prevent any disturbances of the fine salinity gradients being formed. The final salinity and temperature profile was obtained by carefully lowering the sensor downward in the water column. Samples for nutrient analysis, cell counts, cell size measurements and chl $a$ were taken with $10 \mathrm{ml}$ syringes through the plugs on the side of the Plexiglas tank (including the depth of the halocline) and in the surface, initially, once during the experiments, and once at the end. To find the correct value for total cell concentration at the end (including possible bottom-dwelling cells), the content of the water column was mixed before sampling. Nitrate concentration was measured by an optical method as described by Collos et al. (1999) and phosphate concentration as described by Parsons et al. (1992).

Cell counts, cell measurements and chl a analyses were done as for the growth experiments. Patchy distribution of $P$. reticulatum during light hours was visually observed in the upper layer in all experiments. Due to a more homogenous distribution during the dark cycle, cell concentrations were estimated during dark hours and growth rate $(\mu)$ was calculated as given above for growth experiments. To document patchiness, photos, time-lapse recordings and video recordings were used (Nikon Coolpix 5400). To be able to handle the sample data from each experiment, consisting of between 1500 and 5000 data files, the data program R (www. r-project.org/) was used.

\section{Calibration and statistics}

The relationship between light attenuation and cell concentration was obtained by calibration before each experiment in the AWCEMOS, conducted in a smaller tank with the same depth and width as the water column, but a reduced height $(34.5 \mathrm{~cm}$; method described by Erga et al. 1999). Cultures used for calibration were grown under the same conditions as the cultures used in the experiments and were undergoing exponential growth. There were only small differences in the regression coefficient between the different calibrations, and in all cases $\mathrm{r}^{2}$ was higher than 0.99 (data not shown). The lower threshold for cell detection is $<100$ cells ml$^{-1}$. The SE given in Tables $2 \& 4$ is based on 3 parallels or more, and 3 separate 1-way ANOVAs were run for growth of Pret01/12 across experimental gradients (groups) in salinity, temperature and irradiance (IBM SPSS Statistics version 22).

\section{RESULTS}

\section{Growth and light acclimation}

Pret01/12 showed maximum growth rates at irradiances of 150 to $400 \mu \mathrm{mol}$ photons $\mathrm{m}^{-2} \mathrm{~s}^{-1}(0.268-$ $\left.0.295 \operatorname{div~} \mathrm{d}^{-1}\right)$, temperature of $20^{\circ} \mathrm{C}\left(0.284 \operatorname{div~d}^{-1}\right)$ and salinities of 20-34 psu (0.252-0.302 div d $\mathrm{d}^{-1}$; Table 2). It should be noted that Pret01/12 did not grow at irradiances of $25 \mu \mathrm{mol}$ photons $\mathrm{m}^{-2} \mathrm{~s}^{-1}$ and it was also poor at $50 \mu \mathrm{mol}$ photons $\mathrm{m}^{-2} \mathrm{~s}^{-1}$, but apart from this it grew well at all tested experimental conditions. One-way ANOVA showed a significant difference between the groups (gradients in salinity, temperature and irradiance; $\mathrm{p}<0.01$ ). The highest

Table 2. Growth experiments with Protoceratium reticulatum (Pret01/12 strain). Growth rates, $\mu( \pm \mathrm{SE})$ as influenced by temperature $(\mathrm{T})$, salinity (S) and irradiance. One-way ANOVA shows significant difference between the groups (value range of gradients; $\mathrm{p}<0.01$ )

\begin{tabular}{|lccccc|}
\hline $\mathrm{T}\left({ }^{\circ} \mathrm{C}\right)$ & $\begin{array}{c}\mu \text { (divisions } \\
\left.\mathrm{d}^{-1}\right)\end{array}$ & $\begin{array}{c}\mathrm{S} \\
(\mathrm{psu})\end{array}$ & $\begin{array}{c}\mu \text { (divisions } \\
\left.\mathrm{d}^{-1}\right)\end{array}$ & $\begin{array}{c}\text { Irradiance } \\
(\mu \mathrm{mol} \text { photons } \\
\left.\mathrm{m}^{-2} \mathrm{~s}^{-1}\right)\end{array}$ & $\begin{array}{c}\mu \text { (divisions } \\
\left.\mathrm{d}^{-1}\right)\end{array}$ \\
\hline 5 & & & & & \\
10 & $0.130 \pm 0.008$ & 10 & $0.169 \pm 0.060$ & 25 & No growth \\
15 & $0.217 \pm \pm 0.007$ & 15 & $0.236 \pm 0.016$ & 50 & $0.079 \pm 0.024$ \\
20 & $0.284 \pm 0.015$ & 20 & $0.302 \pm 0.007$ & 75 & $0.165 \pm 0.018$ \\
25 & $0.041 \pm 0.024$ & 30 & $0.252 \pm 0.008$ & 150 & $0.295 \pm 0.025$ \\
& & 34 & $0.285 \pm 0.040$ & 200 & $0.268 \pm 0.033$ \\
& & & & 400 & $0.269 \pm 0.009$ \\
\hline
\end{tabular}


cell concentration obtained for Pret01/12 was $2 \times$ $10^{4}$ cells $\mathrm{ml}^{-1}$ when grown at irradiances of 100 to $400 \mu \mathrm{mol}$ photons $\mathrm{m}^{-2} \mathrm{~s}^{-1}$. From the light-tolerance experiment, we also investigated how light intensity (PAR) affected the chl a content of Pret01/12 cells. The lowest value, $14.4 \mathrm{pg} \mathrm{cell}^{-1}$, occurred at $400 \mu \mathrm{mol}$ photons $\mathrm{m}^{-2} \mathrm{~s}^{-1}$, and the maximum value of $35 \mathrm{pg}$ cell $^{-1}$ was found at $25 \mu \mathrm{mol}$ photons $\mathrm{m}^{-2} \mathrm{~s}^{-1}$ (data not shown). In general, decreasing irradiances resulted in increasing chl a content per cell. At $100 \mu \mathrm{mol}$ photons $\mathrm{m}^{-2} \mathrm{~s}^{-1}$, it was $23.5 \mathrm{pg} \mathrm{cell}{ }^{-1}$. An average cell diameter of $26 \mu \mathrm{m}$ was typical during exponential growth.

\section{Water column experiments}

\section{Halocline longevity}

The stratified water column consisted of an upper brackish layer extending downwards from the surface to the upper part of the halocline $(0-41 \mathrm{~cm})$, a halocline with an initial thickness of $6 \mathrm{~cm}$ and finally a bottom layer extending from 47 to $110 \mathrm{~cm}$. Vertical profiles of salinity during the experimental period are shown for experiment $U_{S}$ with the weakest halocline $(\Delta \mathrm{S}=4 \mathrm{psu})$ as representative for the halocline longevity (Fig. 1).

In previous experiments with AWCEMOS, the sharp halocline was found to persist for the whole

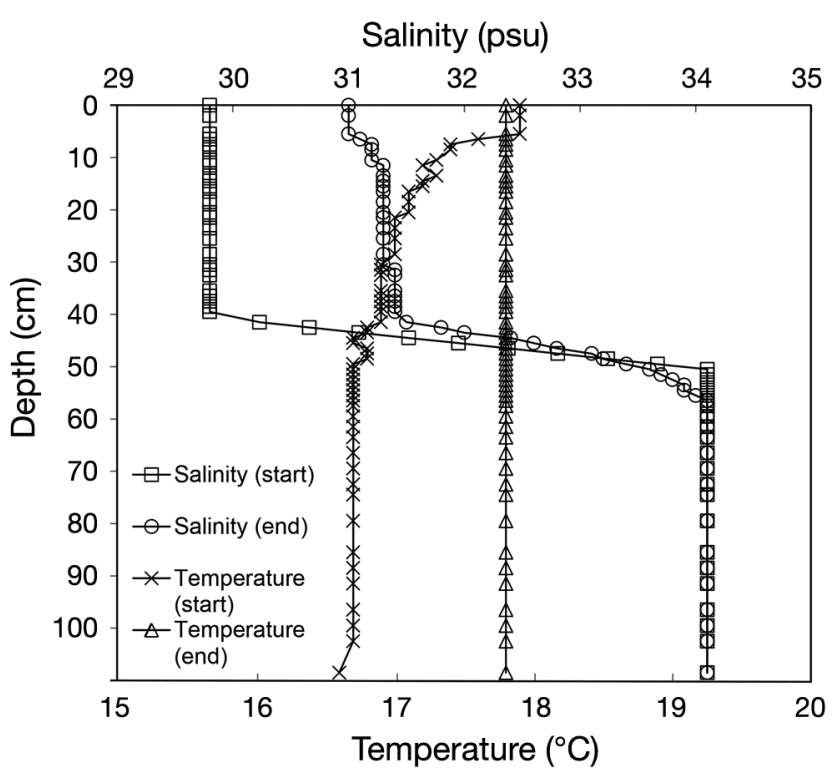

Fig. 1. Salinity and temperature depth profiles at the start and end $(22 \mathrm{~d})$ of experiment Us. See Table 1 for further details of the experiment experimental period, even though duration exceeding 3 to 4 d resulted in increased salinities within the upper layer over time due to evaporation (Erga et al. 2003, 2010, 2015). This also appeared to be the case in the present study. It should be noted, however, that even if the salinity gradient was somewhat weakened during the experiments, the halocline kept its sharpness (i.e. the depth interval over which changes in salinity take place), even in the case of the weakest halocline. The temperature inside the water column was close to room temperature during the experiments.

\section{Vertical migration patterns}

In all experiments, illumination was from above, giving a surface PAR of $100 \mu \mathrm{mol}$ photons $\mathrm{m}^{-2} \mathrm{~s}^{-1}$ with an LD of 14:10 h (see Table 1 for the full experimental conditions). Effort was made to keep the room temperature stable during the experiments (around $18-20^{\circ} \mathrm{C}$ ) and to avoid temperature differences between the water inside the AWCEMOS and the air outside. Values for calculated average cell concentrations are for the entire water column.

In $U S$, the start concentration of the inoculation layer (top 19.2 l) was 1110 cells ml$^{-1}$ (Table 1), equivalent to an average cell concentration of 136 cells $\mathrm{ml}^{-1}$. Pret01/12 showed a clear DVM pattern (Fig. 2a). During the first night, the cells descended and gathered in a visible band right above the relatively weak halocline ( $\Delta \mathrm{S}=4.5 \mathrm{psu})$. After $2 \mathrm{~d}$, the population started a vertical migration pattern which repeated itself for the rest of the experiment (2-22 d); the cells started aggregating in the surface during light periods and spread out evenly above the halocline in the dark periods (Fig. 2b,c). After the light period began, it typically took 30 min for most of the population to gather at the surface (Fig. 2c) and correspondingly $3 \mathrm{~h}$ to be evenly distributed above the halocline after the light was turned off (Fig. 2c,d). The algal population did not migrate below the halocline, which was confirmed by microscopic investigation of cell samples. At the end (Day 22), there were 6000 cells $\mathrm{ml}^{-1}$ (based on $10 \mathrm{ml}$ sampling volume) at the surface. The average algal concentration for the

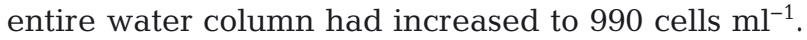

US had a start concentration (in the top 18.9 l) of 2200 cells $\mathrm{ml}^{-1}$ (Table 1), resulting in an average initial cell concentration for the whole water column of 270 cells ml $\mathrm{ml}^{-1}$. Pret01/12 in this experiment showed a similar diel migration pattern as in Us (see above), staying near the surface during the day and spread- 

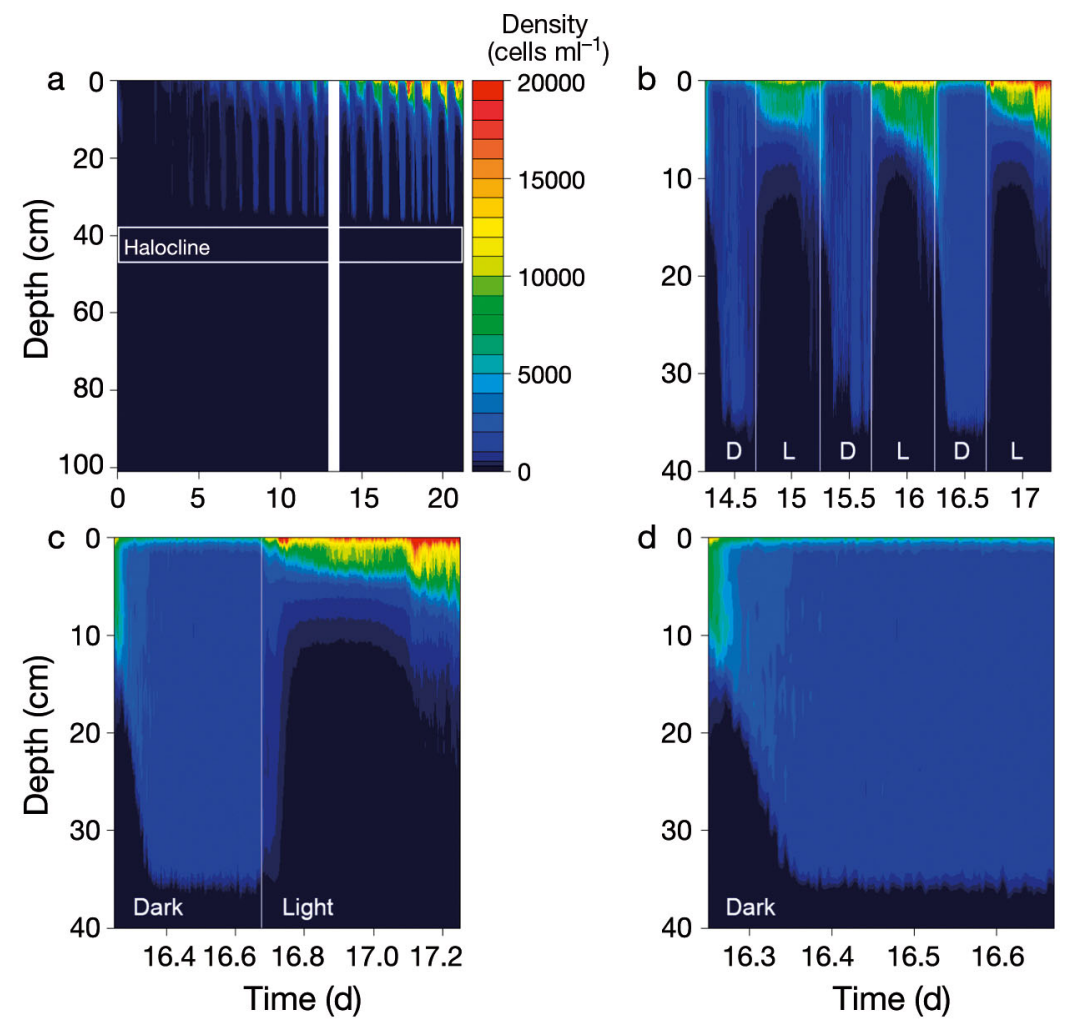

Fig. 2. (a) Diel vertical migration pattern of Protoceratium reticulatum (Pret01/12 strain) in experiment $U_{S}$ (cells introduced above $\Delta \mathrm{S}=34-30 \mathrm{psu}$, where $\Delta \mathrm{S}$ is the difference in salinity between the upper and lower layer) during the whole experimental period (22 d). (b) High time resolution during 3 consecutive days (14-17). Detailed view during (c) 1 diel cycle (Day 16) and (d) 1 dark cycle (Day 16). Irradiance at the surface was $100 \mu \mathrm{mol}$ photons $\mathrm{m}^{-2}$ $\mathrm{s}^{-1}$, with a photoperiod of 14:10 h light:dark (L:D); seawater temperature was $18^{\circ} \mathrm{C}$. The position of the halocline $(\Delta \mathrm{S})$ in (a) is marked by horizontal lines. Note that panels b, c and d show the upper layer only. See Table 1 for details of the experiment

ing out evenly above the halocline at night (data not shown). During the day, the algae assumed a patchy distribution pattern near the surface, often outside the laser detection path. Pret01/12 cells did not descend below the strong halocline $(\Delta \mathrm{S}=13.9 \mathrm{psu})$ in this experiment which lasted for $18 \mathrm{~d}$. After the light period started, it took about $30 \mathrm{~min}$ for the cells to gather near the surface, and when the light was turned off, it took $7 \mathrm{~h}$ for them to be evenly distributed above the halocline. The cell concentration of the surface layer at the end of the experiment was 13020 cells ml-1. The final cell concentration for the entire water column in US was on average 490 cells $\mathrm{ml}^{-1}$.

$L S$ had a start concentration of 2190 cells ml ${ }^{-1}$ (bottom $19.4 l_{\text {; }}$ Table 1 ) with an average cell concentration of 265 cells $\mathrm{ml}^{-1}$ for the whole water column. When the light source was turned on, the algae immediately started swimming upwards, and the whole population was gathered in a horizontal band, visible at the lower halocline after $1 \mathrm{~d}$, before it was displaced upwards, and from Day 2, cells were concentrated within the entire thickness of the halocline (Fig. 3a). This band was visible throughout the experiment (14 d), but it contained more cells during the day, indicating that a fraction of cells migrated down below the halocline during the night (Fig. 3a,b). Some cells reached the surface after $8 \mathrm{~d}$ (visual observation), but due to their position within the very thin surface layer, these could not be detected by the observing system until Day 10, when the surface layer became thick enough (Fig. 3b). The population that reached the surface assumed the same DVM pattern as observed in the other experiments. During the course of the dark period, cells became more and more evenly distributed above the halocline, but after only $1 \mathrm{~h}$ in the light, most of the cells were aggregated near the surface (Fig. 3c,d). The sub-population in the halocline became smaller towards the end, while the surface population increased. The cell concentration in the halocline was 5050 cells $\mathrm{ml}^{-1}$ on Day 9, but had decreased to 2860 cells $\mathrm{ml}^{-1}$ by the end (Day 14). The cell concentration at the surface layer on Day 14 was 3270 cells $\mathrm{ml}^{-1}$, while the average cell concentration for the whole water column was 430 cells $\mathrm{ml}^{-1}$.

In $L s$, the inoculation layer (bottom 20.2 l) had an algal concentration of 1350 cells ml $^{-1}$ (Table 1), giving an initial average cell concentration for the whole water column of 180 cells $\mathrm{ml}^{-1}$. The population quickly ascended to the halocline (data not shown). Some cells were able to cross the halocline $(\Delta \mathrm{S}=$ $4.3 \mathrm{psu})$ at an early phase; they could be observed visually in the surface after $2 \mathrm{~d}$, but were not detected by the optical system (surface cell layer too thin, see comments above) until Day 4. After $5 \mathrm{~d}$, most of the cells had reached the surface and remained there for the rest of the experiment ( $22 \mathrm{~d}$ ). This population attained the same light-dark migration pattern above the halocline as in the other experiments. After $9 \mathrm{~d}$, a sub-population of $393 \mathrm{cells} \mathrm{ml}^{-1}$ was still found in the halocline, but decreasing to 80 cells ml ${ }^{-1}$ in the end. Very few cells were found below the halocline during the experiment (30 cells 

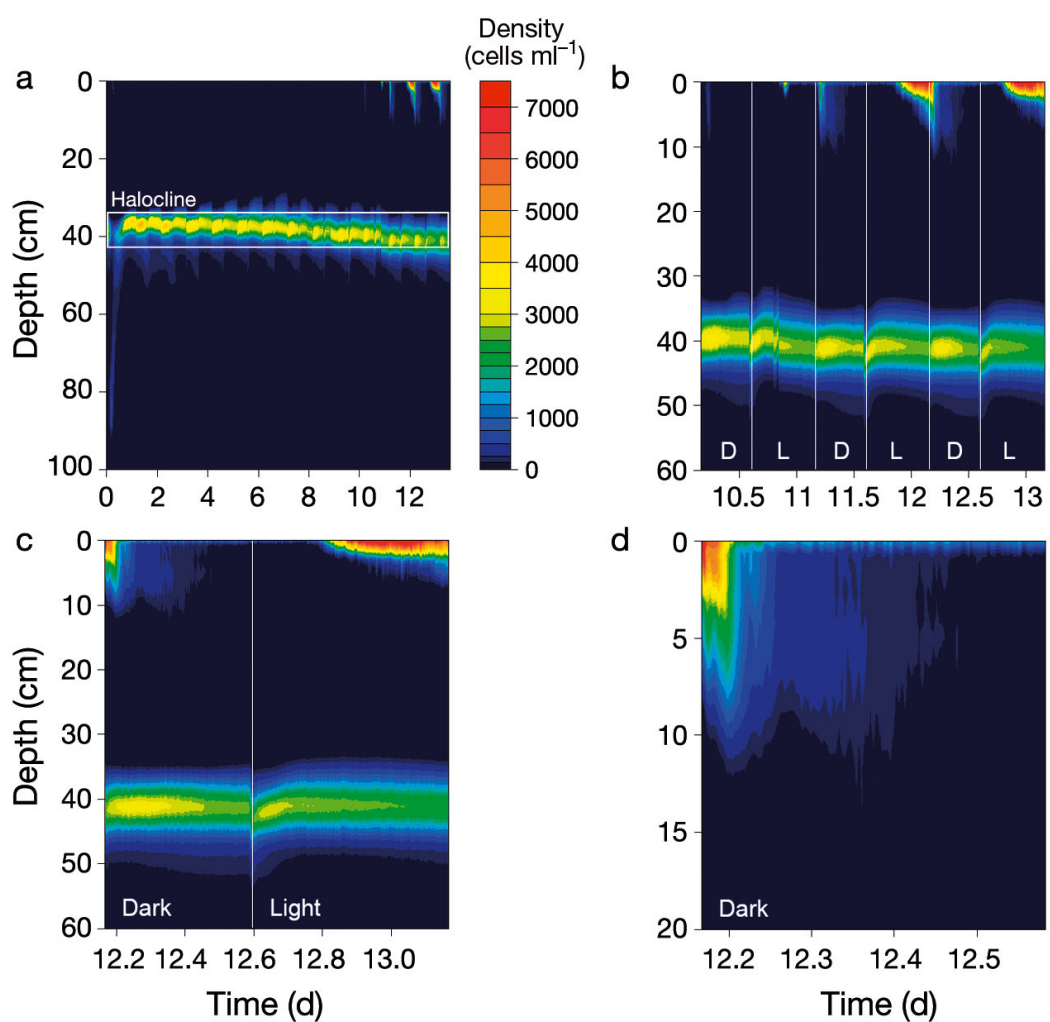

d

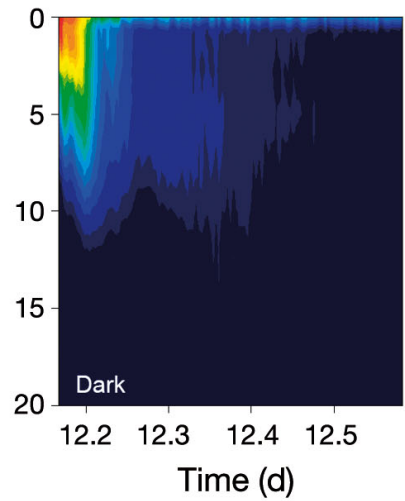

Fig. 3. (a) Diel vertical migration pattern of Protoceratium reticulatum (Pret01/12 strain) in experiment $L S$ (cells introduced below $\Delta \mathrm{S}=34-20 \mathrm{psu}$, where $\Delta \mathrm{S}$ is the difference in salinity between the upper and lower layer) during the whole experimental period (14 d). (b) High time resolution during 3 consecutive days (10-13). Detailed view during (c) 1 diel cycle (Day 12) and (d) 1 dark cycle (Day 12). Irradiance at the surface was $100 \mu \mathrm{mol}$ photons $\mathrm{m}^{-2} \mathrm{~s}^{-1}$, with a photoperiod of 14:10 h L:D; seawater temperature was $20^{\circ} \mathrm{C}$. The position of the halocline $(\Delta \mathrm{S})$ in (a) is marked by horizontal lines. See Table 1 for details of the experiment

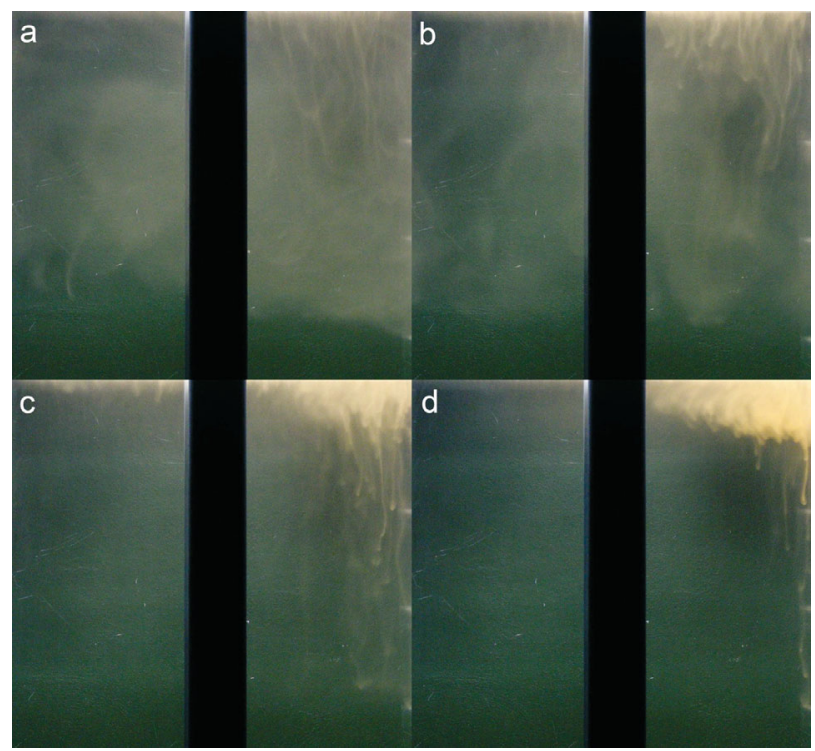
20 min (Fig. 4b). During this phase, the upwards migrating cells showed a strong positive phototactic behaviour, and most of the cells were located in the top $10 \mathrm{~cm}$ within $1 \mathrm{~h}$ (Fig. 4c). Horizontal plumes of algae also formed, pointing towards the main cell aggregate. After $4 \mathrm{~h}$ and $15 \mathrm{~min}$, all of the algae were concentrated in 1 large patch (Fig. 4d), and below it,

Fig. 4. Cell aggregation and cluster/plume formation of Protoceratium reticulatum (Pret01/12 strain) at the surface during the light cycle on Day 16 in experiment Us (cells introduced above $\Delta \mathrm{S}=34-30 \mathrm{psu}$, where $\Delta \mathrm{S}$ is the difference in salinity between the upper and lower layer) after (a) $4 \mathrm{~min}$, (b) $24 \mathrm{~min}$, (c) $60 \mathrm{~min}$ and (d) $255 \mathrm{~min}$. Irradiance at the surface was $100 \mu \mathrm{mol}$ photons $\mathrm{m}^{-2} \mathrm{~s}^{-1}$, with a photoperiod of 14:10 h L:D; seawater temperature was $18^{\circ} \mathrm{C}$. Note that after the dark cycle, cells were evenly distributed above the halocline $(\Delta \mathrm{S})(\mathrm{a})$. The black vertical bar is part of the frame supporting the Plexiglas water column. See Table 1 for details of the experiment 
bioconvectional plumes/droplets of cells were formed during the early light hours. The falling plumes did not penetrate the halocline in any of the experiments, but when they reached the halocline, they flattened out and dissolved before ascending towards the surface as individual cells. However, sometimes the upward migration could be observed as clouds/ aggregates of algae in the water on the side of the descending plumes (detected in a time-lapse movie). In Fig. 5, a detailed time lapse (70-165 min into the light period on Day 7) of bioconvectional plume formation and falling is shown for the US experiment. The first sinking plumes were seen after 85 to $90 \mathrm{~min}$ in the light (Fig. 5d,e), and after $110 \mathrm{~min}$, dense descending plumes reached the halocline (Fig. 5i). Accumulation of cells at the halocline could be seen as cloud formation that occurred after about $130 \mathrm{~min}$ (Fig. 5m). Time lapse movies and a video file of the falling bioconvection plumes/droplets are included in the Supplement, available at www.int-res.com/ articles/suppl/m539p047_supp/.

\section{Nutrients}

In $U S$, the nitrate and phosphate concentration of the top layer after inoculation was 67.5 and $12.4 \mu \mathrm{mol}$ $1^{-1}$, respectively (Table 3 ). At the end (Day 18), the top layer had a nitrate concentration of $18.2 \mu \mathrm{mol}^{-1}$ and phosphate concentration of $2.7 \mu \mathrm{mol} \mathrm{l}^{-1}$. The bottom layer had around $9 \mu \mathrm{mol} \mathrm{l}^{-1}$ nitrate and $1 \mu \mathrm{mol} \mathrm{l}^{-1}$ phosphate both at the beginning and end.

In $U_{S}$, nitrate and phosphate concentrations in the top layer after inoculation decreased from 68.8 and $7.1 \mu \mathrm{mol} \mathrm{l}^{-1}$, respectively, to 1 and $1 \mu \mathrm{mol} \mathrm{l}^{-1}$ at the end (Table 3). In the bottom layer, below the halocline, the nitrate concentration remained at around $10 \mu \mathrm{mol} \mathrm{l}^{-1}$ and the phosphate concentration at $0.7 \mu \mathrm{mol} \mathrm{l}^{-1}$ throughout the experiment.

In $L S$, the nitrate concentration in the bottom layer after inoculation was $86 \mu \mathrm{mol} \mathrm{l}^{-1}$ and phosphate concentration was $9 \mu \mathrm{mol} \mathrm{l}^{-1}$ (Table 3$)$. The initial nitrate and phosphate concentrations of the top layer were 11.0 and $1.0 \mu \mathrm{mol} \mathrm{\textrm {l } ^ { - 1 }}$, respectively. In the end, the nitrate concentration in the surface layer was $2.3 \mu \mathrm{mol} \mathrm{l}^{-1}$ and phosphate concentration was $0.25 \mu \mathrm{mol} \mathrm{l}^{-1}$.

In $L s$, the nitrate and phosphate concentrations in the bottom layer after

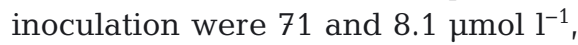

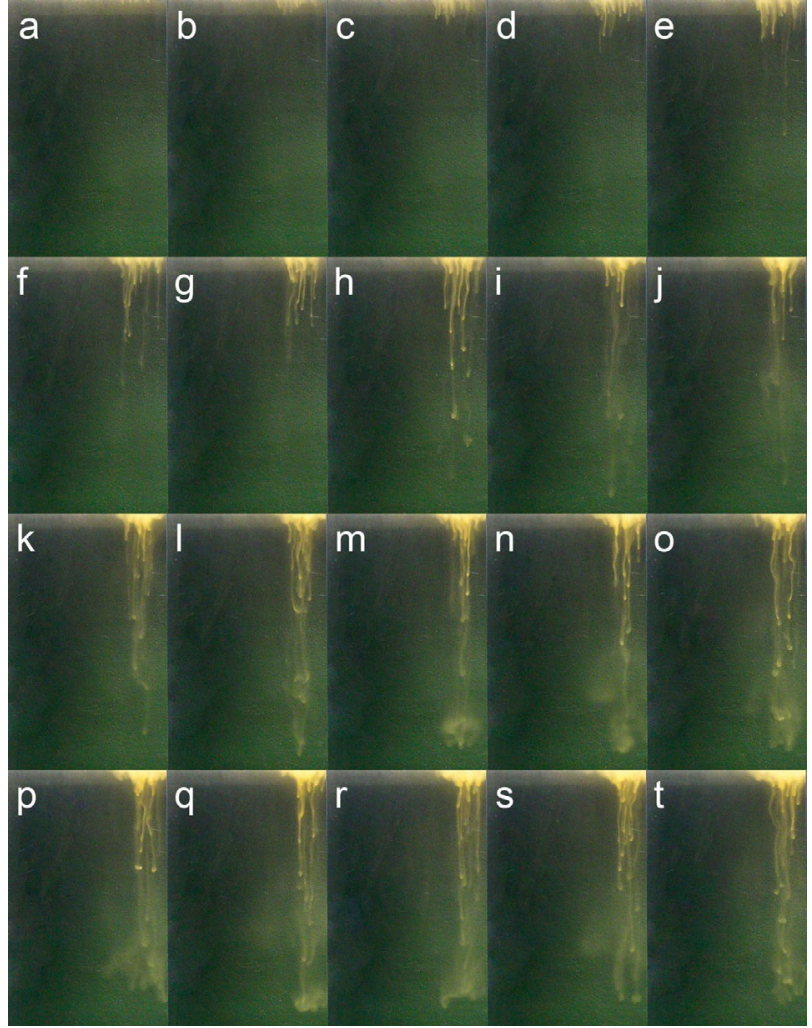

Fig. 5. High-resolution time lapse of bioconvectional plume formation of Protoceratium reticulatum (Pret01/12 strain) in the upper layer during the light cycle on Day 7 in experiment US (cells introduced above $\Delta \mathrm{S}=34-20 \mathrm{psu}$, where $\Delta \mathrm{S}$ is the difference in salinity between the upper and lower layer) at 5 min intervals from (a) 70 min to (t) 165 min into the light cycle. Irradiance at the surface was $100 \mu \mathrm{mol}$ photons $\mathrm{m}^{-2} \mathrm{~s}^{-1}$, with a photoperiod of 14:10 h L:D; seawater temperature was $18.2^{\circ} \mathrm{C}$. The position of the upper halocline $(\Delta \mathrm{S})$ is consistent with maximum downward extension of the plumes. Notice the droplets (small vesicles) on the outside of the vertical plumes. The depth scale is $40 \mathrm{~cm}$. See Table 1 for details of the experiment

Table 3. Initial and final concentrations of nitrate and phosphate for the experiments with Protoceratium reticulatum (Pret01/12 strain) in the artificial water column. Us and $U S$, and $L s$ and $L S$ indicate that the cells were introduced in the upper $(U)$ or lower $(L)$ layer with a strong $(S)$ or weak $(s)$ halocline. Samples were taken at the surface and at the bottom of the water column. For further details on experimental conditions see Table 1

\begin{tabular}{|c|c|c|c|c|c|c|c|c|}
\hline \multirow[t]{3}{*}{ Experiment } & \multicolumn{4}{|c|}{ Nitrate $\left(\mu \mathrm{mol} \mathrm{l^{-1 }}\right)$} & \multicolumn{4}{|c|}{ Phosphate $\left(\mu \mathrm{mol} \mathrm{l} \mathrm{l}^{-1}\right)$} \\
\hline & \multicolumn{2}{|c|}{ Surface } & \multicolumn{2}{|c|}{ Bottom } & \multicolumn{2}{|c|}{ Surface } & \multicolumn{2}{|c|}{ Bottom } \\
\hline & Start & End & Start & End & Start & End & Start & End \\
\hline US & 67.5 & 18.2 & 11.0 & 7.9 & 12.4 & 2.7 & 1.0 & 0.9 \\
\hline$U_{S}$ & 68.8 & 1.0 & 10.7 & 10.3 & 7.1 & 1.0 & 0.7 & 0.7 \\
\hline$L S$ & 11.0 & 2.3 & 86.1 & 11.3 & 1.0 & 0.2 & 9.0 & 0.7 \\
\hline$L s$ & 11.0 & 6.7 & 71.4 & 25.8 & 0.6 & 0.5 & 8.1 & 2.1 \\
\hline
\end{tabular}


respectively (Table 3). Above the halocline, the initial nutrient concentrations were $11 \mu \mathrm{mol} \mathrm{l}^{-1}$ nitrate and $0.6 \mu \mathrm{mol} \mathrm{l}^{-1}$ phosphate, and at the end they were 6.7 and $0.5 \mu \mathrm{mol} \mathrm{\textrm {l } ^ { - 1 }}$, respectively. At $65.5 \mathrm{~cm}$ depth (below the halocline), the nitrate concentration was $25.8 \mu \mathrm{mol} \mathrm{l}^{-1}$ and phosphate was $2.1 \mu \mathrm{mol} \mathrm{l}^{-1}$ at the end.

\section{DISCUSSION}

The environmental conditions (light, salinity, temperature and nutrients) used in our water column experiments (AWCEMOS) are representative for the stratified part of the water column during summer in southern Norwegian fjords and coastal waters (Erga \& Heimdal 1984, Erga 1989, Erga et al. 2005, 2012). An irradiance of $100 \mu \mathrm{mol}$ photons $\mathrm{m}^{-2} \mathrm{~s}^{-1}$ is typically encountered at the lower part of the halocline/upper nutricline (10 to $15 \mathrm{~m}$ depth) during sunny summer days.

\section{Growth}

Both maximum cell concentration $\left(2.1 \times 10^{4}\right.$ cells $\left.\mathrm{ml}^{-1}\right)$ and growth rate $\left(0.3 \mathrm{div} \mathrm{d}^{-1}\right)$ obtained in our growth experiments compare well with those given for other strains of Protoceratium reticulatum (Ratti et al. 2007, Montechiaro \& Giordano 2010, Röder et al. 2012). An irradiance of $100 \mu \mathrm{mol}$ photons $\mathrm{m}^{-2} \mathrm{~s}^{-1}$ was sufficient for growth close to maximum, while temperatures $18-20^{\circ} \mathrm{C}$ and salinities $20-34$ psu were within the optimum range (Table 2). Optimal growth conditions for our $P$. reticulatum strain are close to those found for a Pacific strain (Washington, USA, Johannsen 2004). The highest increase in total integrated cell concentration during our water column experiments was obtained in experiment $U_{S}$, giving an average growth rate of $0.13 \mathrm{div} \mathrm{d}^{-1}$. Samples taken directly from the densest surface aggregates of Pret01/12 cells during the water column experiments (US) revealed a maximum cell concentration of $1.3 \times$ $10^{4}$ cells $\mathrm{ml}^{-1}$.

\section{Effect of halocline strength}

A salinity gradient of 30 to $34 \mathrm{psu}$ is consistent with the summer situation in the Norwegian Coastal Current flowing northwards along western Norway, while a halocline of 20 to $34 \mathrm{psu}$ is more similar to the conditions in the fjords (Erga et al. 2005, 2012).
Vertical separation of phytoplankton into sub- and supra-halocline populations is also interesting with respect to horizontal exchanges of water masses driven by estuarine circulation. Fast-swimming dinoflagellates could, by vertical displacement, reach water layers above or below, and thereby be transported to areas where environmental conditions are more favourable for growth. Sub-surface transport of dinoflagellate cells has been observed from more offshore areas to coastal areas like fjords and embayments (Tyler \& Seliger 1981, Pitcher et al. 1998, Raine \& McMahon 1998). The migration ability may also be used to avoid horizontal transport. One example is Gyrodinium dorsum that blooms in the deepest haline layer of Alfacs Bay, an estuarine embayment in the NW Mediterranean Sea, where horizontal transport and advective losses are at the lowest (Garces et al. 1999).

In US (Fig. 2) and US experiments, the cells stayed above the halocline for the duration of the experiment. There was no indication of cells crossing the halocline, irrespective of its strength. Only the $U_{S}$ treatment showed possible nutrient limitation as opposed to the US treatment, which appeared to have high enough nitrate concentration in the top layer to promote growth. It was obvious that the algal population stayed in the upper layer despite low nitrate concentrations $\left(<1 \mu \mathrm{mol} \mathrm{l}^{-1}\right.$ after $\left.22 \mathrm{~d}\right)$, but it should be noted that there is always a small vertical supply of nutrients at the halocline (Hales et al. 2009), and that $P$. reticulatum seems to thrive at low nitrate concentrations as shown by Fan et al. (2003), who found that it can start blooming at a nitrate concentration of $1.9 \mathrm{\mu mol} \mathrm{l}^{-1}$. When Heterocapsa triquetra cells were inserted into the brackish surface layer $(10,15$ or $20 \mathrm{psu})$ of small experimental water columns, they were able to cross salinity gradients of 6 and $11 \mathrm{psu}$, but not 16 psu, while Prorocentrum minimum did not cross any of the salinity gradients from below (bottom salinity 26 psu; Jephson et al. 2011). A study by Rasmussen \& Richardson (1989) showed that Alexandrium tamarense (formerly Gonyaulax tamarensis) could not cross haloclines of more than 7 psu, but the ability was also dependent on light intensity. Still more special are Ceratium furca, C. tripos and Dinophysis sp., which were not able to cross a salinity gradient of $5 \mathrm{psu}$, neither from above nor from below the halocline (Jephson \& Carlsson 2009). These data and results from our study suggest that there are great variations among dinoflagellates concerning their ability to conduct DVM between nutrient-depleted surface waters and sub-halocline nutrient-replenished waters. Such different behaviour 
could be due to the fact that mixotrophy is also widespread among phototrophic dinoflagellates (Jeong et al. 2010).

When the inoculum was inserted in the bottom layer, the cells were able to pass the weaker halocline in $L s(\Delta \mathrm{S}=4.3 \mathrm{psu})$ after $4 \mathrm{~d}$ and the stronger halocline in $L S$ ( $\Delta \mathrm{S}=14.1 \mathrm{psu}$ ) after 8 (visually) to $10 \mathrm{~d}$ (Fig. 3). As pointed out in an earlier study with the prasinophyte Tetraselmis sp., time-dependent osmotic adaptation is probably involved for the cells crossing the halocline (see Erga et al. 2003). For the red-tide algae Chattonella antiqua (Raphidopyceae) and Karenia mikimotoi (Dinophyceae), it was found that neither could transit haloclines of $\Delta \mathrm{S}=22-27 \mathrm{psu}$ during the day, while $K$. mikimotoi needed $2 \mathrm{~d}$ to cross $\Delta \mathrm{S}=12 \mathrm{psu}$ and $4 \mathrm{~d}$ to $\operatorname{cross} \Delta \mathrm{S}=17 \mathrm{psu}$ (Shikata et al. 2014). This is in contrast to Heterosigma akashiwo (Raphidopyceae), where no delays in swimming could be observed for cells crossing salinity jumps of 28 to 16 psu (Bearon et al. 2006).

Gonyaulax and Cachonina species lose their ability to conduct vertical migration when nitrate is depleted (Eppley et al. 1968), while in the case of Dinophysis spp., no relationship between nutrient concentration and vertical distribution of cells could be found (Delmas et al. 1992). A. tamarense did not perform DVMs when nitrate was available, but started DVM when the nitrate was depleted (MacIntyre et al. 1997). Ceratium hirundinella migrated a total of $14 \mathrm{~m}$ $\mathrm{d}^{-1}$, but there was no evidence of downward migration to exploit nutrients below the surface layer (Whittington et al. 2000), while Prorocentrum mariae-lebouriae was unable to cross a halocline of 10 to 15 psu (only $36 \mathrm{~h}$ duration; Tyler \& Seliger 1981). As confirmed in experiments $L s$ and $L S$, once ascending cells of Pret01/12 had managed to pass through the halocline, they did not move back to the more nutrient-rich bottom layer. A common pattern was that cells at the lower part of the halocline seemed to have a deeper penetration into the halocline towards the end of the dark period, even if this was most pronounced in the case of $L S$ where a more substantial part of the population remained at the halocline throughout the experimental period (Fig. 3a,b). Early in the light period, cells were again concentrated at the halocline. The accumulation of cells in the surface layer towards the end was probably due to ascending cells that had succeeded in passing through the halocline after 8 to $10 \mathrm{~d}$. Even if the subpopulation near the halocline diminished towards the end, it remained throughout the whole experimental period. Such differentiations in migration behaviour during a relatively short time period (a few days) have been shown for Tetraselmis sp. (Erga et al. 2003). During benthic-pelagic transition in Heterosigma akashiwo, the existence of habitat-specific trade-offs between physiological and/or behavioural traits was important for bloom formation (Tobin et al. 2013). Common for all these studies is the prominence of halocline strength as a key regulator for lifestage transformations. It seems that parts of the population become survivors, typically accumulating at the halocline, and some become swimmers, typically conducting DVM once they have managed to pass through the halocline. Such phenotypic plasticity in migratory behaviour among algal flagellates could serve an important ecological role for both survival and successful expansion into new areas. For HAB species, such knowledge is crucial not only for a better understanding of their bloom dynamics, but also for improving our ability to predict, monitor, mitigate and prevent $\mathrm{HAB}$ events.

\section{Positive phototaxis}

The vertical migration of dinoflagellates is often a response to the diel light cycle, with positive phototaxis controlling upward movement in the light and positive geotaxis controlling downward movement in the dark (MacIntyre et al. 1997, Kamykowski et al. 1998). By such a swimming behaviour, cells could exploit the more nutrient-rich deeper waters during night and stay up in the light during the day (Cullen \& Horrigan 1981, Villarino et al. 1995, MacIntyre et al. 1997, Fauchot et al. 2005, Jephson et al. 2011). Some dinoflagellates, like Gymnodinium bogoriense, start their upward migration towards the end of the dark period (Lieberman et al. 1994), while for the raphidophyte $H$. akashiwo, upward swimming starts early in the light period (Bearon et al. 2004), indicating that an endogenous rhythm (circadian clock) is involved. Also for Prorocentrum minimum, P. micans and Ceratium furca, DVM is due to circadian rhythms (Olsson \& Granéli 1991), while other studies have concluded that the nutrient status of the cells is decisive (Heaney \& Eppley 1981, MacIntyre et al. 1997, Jephson et al. 2011).

The present study has shown that upward migration of Pret01/12 responds directly to light. On 2 occasions, the experimental system stopped for several hours during the light period due to power failure. This resulted in an immediate stop in the ascent (visually observed), which supports positive phototaxis as the main regulating factor, and that a circadian rhythm is not involved. The random distribution 
of Pret01/12 cells above the halocline after some time in darkness, as shown for experiment $U s$ and $U S$, can happen if the swimming cells are influenced both by positive and negative geotaxis (Kamykowski et al. 1998 , 1999), or it can simply be the result of random movements (see Häder et al. 2006, and references therein).

\section{Role of bioconvection and gyrotaxis in vertical migration}

The strong positive phototactic response seen for Pret01/12 resulted in accumulation of cells into convergence zones at the surface (horizontal stripes in the water) during the first light hours in experiments Us and US. Such a pattern has been observed for other flagellated microalgae as well, and is similar to what happens in Langmuir circulation (Bearon \& Grünbaum 2006). In our study, the stripes were formed at an early stage of the experiments, but they vanished after several days. During withdrawal, the cells moved horizontally inwards and became more and more concentrated into 1 main aggregate/patch. For A. fundyense (Dinophyceae), assembly of cells into horizontal bioconvection spots/stripes was restricted to the early stationary phase of the life cycle, and has been explained by life-history-related swimming patterns and/or responses related to water movements (Persson \& Smith 2013). Such patchy and dense aggregations of harmful dinoflagellate cells represent high accumulations of biomass which can facilitate transfer of algal toxins to higher trophic levels (Manfrin et al. 2012).

It took many days of growth (about $1 \mathrm{wk}$ ), however, before cell concentrations became high enough $\left(3-5 \times 10^{3}\right.$ cells $\left.\mathrm{ml}^{-1}\right)$ to cause density instability in the surface layer and thereby start a massive descent of cells. It is interesting to note that this took longer time in $U s$ than in $U S$, probably due to lower initial cell concentrations in Us than US (Table 1). From this moment, vertical migration was dominated by fastsinking plumes of cells, extending progressively deeper during the light period and lasting for several days, but it was always stopped by the halocline. The maximum cell concentration $\left(1.3 \times 10^{4}\right.$ cells $\left.\mathrm{ml}^{-1}\right)$ observed within the surface aggregates (see above) is close to that predicted from the equation of Agustí et al. (1987) relating algal cell size and maximum achievable cell concentration during exponential growth (we used an average radius of $13 \mu \mathrm{m}$ and a cell volume of $10^{4} \mathrm{\mu m}^{3}$ for Pret01/12). When presenting their bioconvection model, Pedley \& Kessler
(1992) used the chlorophyte Chlamydomonas nivalis as the experimental organism, while Bearon \& Grünbaum (2006) used the raphidophyte $H$. akashiwo in their bioconvection study. These algae are roughly of the same size, with radius around $6 \mu \mathrm{m}$ and volume

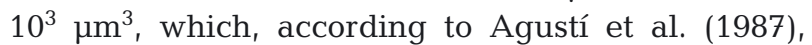
should give a maximum cell concentration of $2 \times$ $10^{5}$ cells ml ${ }^{-1}$. This is on a scale 10 times lower than the concentration $\left(10^{6}\right.$ cells ml $\left.{ }^{-1}\right)$ reported to initiate bioconvection for $C$. nivalis and $H$. akashiwo. It therefore seems that for those species, bioconvection did not occur before the surface aggregates were overloaded with cells, indicating that some other behavioural response must be involved. It has been suggested that when swimming cells come close to each other, they move in the same direction due to behavioural interactions (Bearon et al. 2004), probably including some type of signalling.

A fundamental premise for the bioconvection theory is that the circulation pattern is maintained by gyrotactic swimming, a behavioural response characterized by the upward swimming direction being inclined to the vertical (Pedley \& Kessler 1992). A prerequisite in this context is that the swimming cells are bottom heavy (like $P$. reticulatum) and thereby are able to orient themselves by a balance between viscous and gravitational torque (Pedley \& Kessler 1992, Bearon \& Grünbaum 2006, Karimi \& Ardekani 2013, Zhan et al. 2014). The viscous torque is due to the vertical shear force formed between the dense falling plume and the upwards swimming cells. Therefore, gyrotaxis is important for the maintenance of the self-focussing bioconvective plumes (Bearon \& Grünbaum 2006). We could not observe any morphological changes during the experiments, such as resting stages and/or cysts, which could otherwise have stopped the bioconvection pattern due to the immobility of resting stages (Han et al. 2002) or led to increased descent/sinking of cysts down below the halocline (Anderson et al. 1985).

Karimi \& Ardekani (2013) applied a continuum model based upon Navier-Stokes equations together with linear stability analysis and large-scale 3dimensional numerical simulations to foresee how gyrotactic bioconvection could affect spatial distribution of microorganisms in a water column with a constant linear salinity gradient. They concluded that the downwards extension of the bioconvection plume is regulated by the pycnocline. The results from our experiments with Pret01/12 in the water column showed that the bioconvectional circulation was stopped at the halocline, even at a strength of only 4 psu. 


\section{Vertical migration speeds}

Dinoflagellates usually do not swim straight forward, but rather in helical paths. The upward swimming speed of Pret01/12 was determined by following the movement of the algae in the beginning of experiments $L s$ and $L S$, where algae were inserted in the bottom layer and kept close to the bottom with a light source from below. When the $L S$ experiment was started by turning on the light from above and switching off the light from below, the algae started swimming upwards, and it took less than 5 min before algae could be detected in the halocline (Fig. 6). After $15 \mathrm{~min}$, a large part of the population had reached the halocline. This gives an estimated maximum swimming speed of $4.0 \mathrm{~m} \mathrm{~h}^{-1}$, placing $P$. reticulatum among the fastest dinoflagellates. In other studies, maximum swimming speeds of $1.7 \mathrm{~m} \mathrm{~h}^{-1}$ were achieved at a temperature of $24^{\circ} \mathrm{C}$ for cells of $A$. minutum (Lewis et al. 2006) and $1.5 \mathrm{~m} \mathrm{~h}^{-1}$ for cells of Karenia brevis at a temperature range of 17 to $30^{\circ} \mathrm{C}$ (McKay et al. 2006). Peridinium gregarium and Protoperidinium cf. quinquecorne can reach maximum swimming speeds of 5 to $6 \mathrm{~m} \mathrm{~h}^{-1}$, while most other dinoflagellates show maximum swimming speeds of $\sim 1 \mathrm{~m} \mathrm{~h}^{-1}$ (references summarized by Levandowsky \&

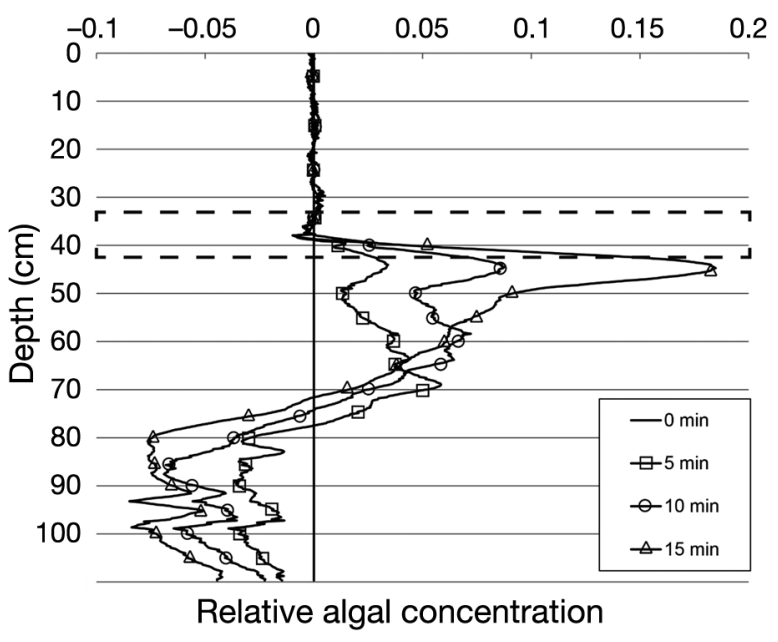

Fig. 6. Upward migration of Protoceratium reticulatum (Pret01/12 strain) from the bottom layer and cell aggregation at the lower halocline $(\Delta \mathrm{S})$ during the first $15 \mathrm{~min}$ of the light cycle in experiment $L S$ (cells introduced in the lower layer below $\Delta \mathrm{S}=34-20 \mathrm{psu})$. Dashed lines: halocline $(\Delta \mathrm{S})$. Irradiance at the surface was $100 \mu \mathrm{mol}$ photons $\mathrm{m}^{-2} \mathrm{~s}^{-1}$, with a photoperiod of 14:10 h L:D; seawater temperature was $20^{\circ} \mathrm{C}$. Changes toward positive relative numbers reveal increased algal concentrations and negative numbers indicate decreased concentrations. See Table 1 for details of the experiment
Kaneta 1987). In a previous experiment with AWCEMOS, the maximum estimated swimming speed of the green flagellate Tetraselmis sp. (7-10 $\mu$ m length) was found to be $0.9 \mathrm{~m} \mathrm{~h}^{-1}$. The average upward swimming speed of our Pret01/12 population was estimated from experiments Us and US by following the ascent from the halocline towards the surface early in the light period, and were within the range $0.50( \pm 0.073 \mathrm{SE})$ to $0.58( \pm 0.140) \mathrm{m} \mathrm{h}^{-1}$ (data not shown). For the raphidophyte H. akashiwo (12-18 $\mu \mathrm{m}$ length), average upward swimming speed was computed to be $0.14 \mathrm{~m} \mathrm{~h}^{-1}$ (Bearon \& Grünbaum 2008).

The downward displacement speeds of Pret01/12 for all experiments were estimated during the dark period $(10 \mathrm{~h})$ by examining plots of the algae during 3 nights of each experiment and measuring the position of the algal front (i.e. depth of the most dense cell propagation) during an early phase of the dark period to see how fast the algal front descended within the upper layer. The mean descent speed was $0.08 \mathrm{~m} \mathrm{~h}^{-1}$ for experiments $U s$ and $L s$, significantly higher than the $0.03 \mathrm{~m} \mathrm{~h}^{-1}$ found for $U S$ and $L S$ (Table 4). This is not to be expected if passive sinking should play a major role for the downward displacement speed, due to the fact that buoyancy is lower in salinity of 20 psu (US and $L S$ ) than $30 \mathrm{psu}$ (Us and $L s$ ). According to Stokes' law, the sinking velocity $v\left(\mathrm{~m} \mathrm{~s}^{-1}\right)$ of a spherical particle can be calculated as:

$$
v=2 g r^{2}\left(\rho_{p}-\rho_{s W}\right) / 9 \eta \Phi
$$

where $r$ is the radius of the particle, $g$ is the gravitational acceleration, $\rho_{p}$ and $\rho_{s w}$ are the density of the particles and seawater, respectively, $\eta$ is the dynamic viscosity of seawater, and $\Phi$ is the shape factor of the cell. Shape factor was set to 1 , because Kamykowski et al. (1992) found shape to have very little influence on the sinking speed of a cell. Cell density was set to $1.084 \mathrm{~g} \mathrm{~cm}^{-3}$, which is the same as the density of Gonyaulax polyedra (Kamykowski et al. 1992), since

Table 4. Average descent speeds of Protoceratium reticulatum (Pret01/12 strain) in the artificial water column for cells being introduced above (upper layer, $U$ ) or below (lower layer, $L)$ a strong $(S)$ or weak halocline $(s)$. For further details on experimental conditions see Table 1

\begin{tabular}{|lcc|}
\hline Experiment & $\begin{array}{c}\text { Salinity } \\
(\mathrm{psu}) U: L\end{array}$ & $\begin{array}{c}\text { Displacement replaced by } \\
\pm \text { descent speed }\left(\mathrm{m} \mathrm{h}^{-1}\right) \pm \mathrm{SE}\end{array}$ \\
\hline$U S$ & $19.9: 33.8$ & $0.033 \pm 0.001$ \\
$U S$ & $30: 34.5$ & $0.080 \pm 0.005$ \\
$L S$ & $20: 34.1$ & $0.035 \pm 0.001$ \\
$L S$ & $29.8: 34.1$ & $0.076 \pm 0.003$ \\
\hline
\end{tabular}


G. polyedra is closely related to $P$. reticulatum and is about the same size. The dynamic viscosity ( $\eta$ ) of seawater with a salinity of 20 and $30 \mathrm{psu}$, and temperature of $20^{\circ} \mathrm{C}$ was set to 0.0104 and $0.0106 \mathrm{~g} \mathrm{~cm}^{-1} \mathrm{~s}^{-1}$, respectively (S. Sundby pers. comm.). The radius of the cells at salinities $\sim 20$ and $\sim 30$ psu were found by measuring the length and width of 40 cells from experiment $L S$ and $U S$, and setting the diameter of the cell to the average of the length and width. The difference between the numbers, $13.2 \mu \mathrm{m}$ (30 psu) versus $12.8 \mu \mathrm{m}$ (20 psu), is not significant, but was nevertheless used in the calculations. From this, one gets a theoretical sinking speed of $0.077 \mathrm{~m} \mathrm{~h}^{-1}$ for the high-salinity experiments $U s$ and $L s$ and $0.085 \mathrm{~m} \mathrm{~h}^{-1}$ for the low-salinity experiments $L S$ and US. Only in the case of the high-salinity experiments is there a match with measured data. However, our results show that $P$. reticulatum cells are randomly distributed above the halocline in the dark period, indicating active swimming in darkness (Fig. 2d). The downward displacement is stopped by the halocline, which acts as a physical barrier. Our data also reveal that sub-populations of $P$. reticulatum seem to be swimming upwards to a greater extent in 20 psu than 30 psu water, causing the total downward displacement speed to be slower than for the $30 \mathrm{psu}$ water. Such a swimming response indicates negative geotaxis being stronger, or positive geotaxis weaker, in low-salinity than high-salinity water. From this, we conclude that the $P$. reticulatum population as a whole does not perform regular downward migration at night and that sinking was not pronounced, because in both cases it should cause cells to accumulate/aggregate at the halocline. It therefore seems that cells orient themselves relative to the halocline during the light period by active swimming, while during darkness, cells are not attracted by the halocline, showing a more random distribution in the upper layer.

The vertical bioconvection plumes of $P$. reticulatum occurred after a sufficient growth period $(7 \mathrm{~d})$ and extended down from the surface during the light period, with fast-sinking droplets sliding downwards on the outside of the vertical plumes (see Fig. 5). The droplets could be considered as sinking cell aggregates. The sinking speed of the droplets $(2-5 \mathrm{~mm}$ in diameter) was determined from a video taken during experiment US (available in the Supplement, www. int-res.com/articles/suppl/m539p047_supp/, Movie 3). The average speed of 4 droplets was found to be 5.0 $\mathrm{m} \mathrm{h}^{-1}$, which indicates that $P$. reticulatum cells are able to descend very quickly from the surface and down to the halocline during day time. This sinking speed is faster than the maximum upward swimming speed of $4.0 \mathrm{~m} \mathrm{~h}^{-1}$ found in experiment US. These fast-sinking droplets can be considered as a mechanism of rapid downwards transport of cells superimposed on the bioconvection plumes. In total, this will reduce the bioconvection turnover time. The fact that bioconvection has been observed under calm conditions in natural waters (Bearon \& Grünbaum 2006) strengthens its importance as a regulating factor for the spatial distribution of motile algal cells during blooms, including HAB species. Some of the advantageous effects of such behaviour could be avoidance of strong light at the surface, or a means for cells to encounter nutritional microenvironments, or simply a way to improve the nutritional absorption efficiency. The reason why bioconvectional mixing did not break down the halocline over 14 to $22 \mathrm{~d}$ could be that once the descending cells approach the halocline, they undergo negative salt-taxis (Hershberger et al. 1997) and level out at the base of the plume, free to swim upwards.

Many studies on vertical migration of dinoflagellates are from natural waters. For Cochlodinium polykrikoides, a maximum descent speed of $4 \mathrm{~m} \mathrm{~h}^{-1}$ was found during a red tide in coastal waters of Korea, which was faster than the maximum ascent speed ( $3 \mathrm{~m} \mathrm{~h}^{-1}$; Park et al. 2001). This was explained by gravity having a stimulating effect on the downwards swimming speed. In another study from Ría de Vigo (NW Spain), Scrippsiella trochoidea and Dinophysis acuminata were found to move faster upwards than downwards, while for Ceratium furca the opposite appeared to be the case (Figueroa et al. 1998). The role of bioconvection in these in situ investigations, however, remains uncertain, but it could be speculated that in cases where descent speeds are higher than ascent speeds, it is not unlikely that it contributes to the observed patterns.

Gymnodinium mikimotoi and A. tamarense have been shown to conduct in situ vertical migrations down to $20 \mathrm{~m}$ with a swimming speed of about $2 \mathrm{~m}$ $\mathrm{h}^{-1}$ (Koizumi et al. 1996, Fauchot et al. 2005), while Gonyaulax polyedra reached down to $15 \mathrm{~m}$ during a $24 \mathrm{~h}$ period (day length dependent) at a swimming speed of $1 \mathrm{~m} \mathrm{~h}^{-1}$ (Eppley \& Harrison 1975). For our strain of $P$. reticulatum, such a deep vertical migration does not seem to be a realistic scenario for coastal/fjord waters, where the halocline is normally situated shallower than $10 \mathrm{~m}$, which is above the nutricline. According to our results, when cells had succeeded to cross the halocline from below after a sufficient osmotic adaptation time, they did not descend below again, and cells being introduced in 
the upper layer remained here throughout the experimental period (18-22 d), even if nutrients became scarce and probably limiting. The reason for this could be problems with self-shading due to high cell concentrations (i.e. decreased optical absorption crosssection), which will lead to more favourable light conditions in the upper layer than the bottom layer. It could also be that Pret01/12 cells prefer to stay above the halocline with the purpose of saving energy which would otherwise be spent on light and osmotic acclimations.

\section{CONCLUSIONS}

Growth experiments showed that Protoceratium reticulatum can grow close to maximum $\left(0.3 \mathrm{div} \mathrm{d}^{-1}\right)$ within relatively wide ranges of irradiance (150$400 \mu \mathrm{mol}$ photons $\mathrm{m}^{-2} \mathrm{~s}^{-1}$ ) and salinity (20-34 psu), but a narrow range of temperature (around $20^{\circ} \mathrm{C}$ ). In our experimental water column with salinity stratification, we have shown that positive phototaxis was the causative mechanism for DVM of $P$. reticulatum during the first days, but gyrotactic bioconvection became an integral part of the migration pattern when surface cell concentration became high enough (after $7 \mathrm{~d}$ ). At this stage, fast-sinking $\left(5 \mathrm{~m} \mathrm{~h}^{-1}\right)$ cell plumes/droplets were observed above the halocline during day time, being maintained by gyrotactic behaviour among upwards-swimming cells (average speed $0.6 \mathrm{~m} \mathrm{~h}^{-1}$ ). However, when the night started, the bioconvection mechanism collapsed and the cells were randomly distributed above the halocline after 2 to $3 \mathrm{~h}$, indicating random swimming or a balance between negative and positive geotaxis. It is also interesting to note that once the upward migrating cells had managed to pass the halocline, taking 4 and $8 \mathrm{~d}$ in the case of 4 and 14 psu salinity gradients, respectively, they did not return to the layer below during the dark period. Despite nitrate limitation in the upper layer towards the end in 2 of the experiments, $P$. reticulatum did not migrate down below the halocline where nutrients were sufficient. This seemingly surprising behaviour could be due to energysavings by not performing osmotic adjustments and not producing supplementary pigments. We believe that in persistent calm and stratified environments, bioconvection could be an important regulating factor for cell distributions and DVM during dinoflagellate blooms. It is also possible that the fast and passive transport of cells down to the halocline during the bioconvectional overturn could be a competitive advantage with respect to exploitation of weak nutri- ent diffusion through the halocline. Another aspect of bioconvection with wide ecological consequences is the formation of dense surface patches of cells, which in a predator-prey size relationship could lead to increased trophic transfer efficiency, but at the same time in the case of HAB species, increase the transfer of toxins to higher trophic levels. We hope that our findings will contribute to a better understanding of bloom dynamics during HAB events.

Acknowledgements. We are greatly indebted to technical staff at the Department of Physics and Technology for help with technical solutions and improvements of the experimental water column, and to Svein Nordland and Kjetil Aursland at the Department of Biology for assistance with computerizing the data sampling. The authors are also grateful to the anonymous reviewers for their detailed and constructive comments.

\section{LITERATURE CITED}

Aasen J, Samdal IA, Miles CO, Dahl E, Briggs LR, Aune T (2005) Yessotoxins in Norwegian blue mussels (Mytilus edulis): uptake from Protoceratium reticulatum, metabolism and depuration. Toxicon 45:265-272

Agustí S, Duarte CM, Kalff J (1987) Algal cell size and the maximum density and biomass of phytoplankton. Limnol Oceanogr 32:983-986

> Anderson DM, Lively JJ, Reardon EM, Price CA (1985) Sinking characteristics of dinoflagellate cysts. Limnol Oceanogr 30:1000-1009

Aure J, Strand Ø, Erga SR, Strohmeier T (2007) Primary production enhancement by artificial upwelling in a western Norwegian fjord. Mar Ecol Prog Ser 352:39-52

> Bearon RN, Grünbaum D (2006) Bioconvection in a stratified environment: experiments and theory. Phys Fluids 18: 127102

Bearon RN, Grünbaum D (2008) From individual behaviour to population models: a case study using swimming algae. J Theor Biol 251:679-697

Bearon RN, Grünbaum D, Cattolico RA (2004) Relating celllevel swimming behaviors to vertical distributions in Heterosigma akashiwo (Raphidophyceae), a harmful alga. Limnol Oceanogr 49:607-613

- Bearon RN, Grünbaum D, Cattolico RA (2006) Effects of salinity structure on swimming behaviour and harmful algal bloom formation in Heterosigma akashiwo, a toxic raphidophyte. Mar Ecol Prog Ser 306:153-163

Blasco D (1978) Observations on the diel migration of marine dinoflagellates off the Baja California coast. Mar Biol 46:41-47

> Ciminiello P, Fattorusso E, Forino M, Magno S and others (1997) Yessotoxin in mussels of the northern Adriatic Sea. Toxicon 35:177-183

Collos Y, Mornet F, Sciandra A, Waser N, Larson A, Harrison PJ (1999) An optical method for the rapid measurement of micromolar concentrations of nitrate in marine phytoplankton cultures. J Appl Phycol 11:179-184

Cullen JJ, Horrigan SG (1981) Effects of nitrate on the diurnal vertical migration, carbon to nitrogen ratio, and the photosynthetic capacity of the dinoflagellate Gymnodinium splendens. Mar Biol 62:81-89 
Delmas D, Herbland A, Maestrini SY (1992) Environmental conditions which lead to increase in cell density of the toxic dinoflagellates Dinophysis spp. in nutrient-rich and nutrient-poor waters of the French Atlantic coast. Mar Ecol Prog Ser 89:53-61

Dortch Q, Maske H (1982) Dark uptake of nitrate and nitrate reductase activity of a red-tide population off Peru. Mar Ecol Prog Ser 9:299-303

> Draisci R, Ferretti E, Palleschi L, Marchiafava C and others (1999) High levels of yessotoxin in mussels and presence of yessotoxin and homoyessotoxin in dinoflagellates of the Adriatic Sea. Toxicon 37:1187-1193

Eggersdorfer B, Häder DP (1991) Phototaxis, gravitaxis and vertical migrations in the marine dinoflagellate Prorocentrum micans. FEMS Microbiol Ecol 85:319-326

Eppley RW, Harrison WG (1975) Physiological ecology of Gonyaulax polyedra, a red water dinoflagellate of southern California. In: LoCicero VR (ed) Toxic dinoflagellate blooms. Science and Technology Foundation, Wakefield, MA, p 11-22

Eppley RW, Holmes RW, Strickland JDH (1967) Sinking rates of marine phytoplankton measured with a fluorometer. J Exp Mar Biol Ecol 1:191-208

Eppley RW, Holm-Hansen O, Strickland JDH (1968) Some observations on the vertical migration of dinoflagellates. J Phycol 4:333-340

Erga SR (1989) Ecological studies on the phytoplankton of Boknafjorden, western Norway. I. The effect of water exchange processes and environmental factors on temporal and vertical variability of biomass. Sarsia 74:161-176

Erga SR, Heimdal BR (1984) Ecological studies on the phytoplankton of Korsfjorden, western Norway. The dynamics of a spring bloom seen in relation to hydrographical conditions and light regime. J Plankton Res 6:67-90

Erga SR, Omar AM, Singstad I, Steinseide E (1999) An optical detection system for the study of fine-scale vertical displacement of microalgae in an artificial water column. J Phycol 35:425-432

Erga SR, Dybwad M, Frette Ø, Lotsberg JK, Aursland K (2003) New aspects on migratory behaviour of phytoplankton in stratified waters: effects of halocline strength and light on Tetraselmis sp. (Prasinophyceae) in an artificial water column. Limnol Oceanogr 48:1202-1213

Erga SR, Aursland K, Frette Ø, Hamre B and others (2005) UV transmission in Norwegian marine waters: controlling factors and possible effects on primary production and vertical distribution of phytoplankton. Mar Ecol Prog Ser 305:79-100

Erga SR, Lie GC, Aarø LH, Aursland K, Olseng CD, Frette Ø, Hamre B (2010) Fine scale vertical displacement of Phaeodactylum tricornutum (Bacillariophyceae) in stratified waters: influence of halocline and day length on buoyancy control. J Exp Mar Biol Ecol 384:7-17

Erga SR, Ssebiyonga N, Frette Ø, Hamre B, Aure J, Strand $\varnothing$, Strohmeier T (2012) Dynamics of phytoplankton distribution and photosynthetic capacity in a western Norwegian fjord during coastal upwelling: effects on optical properties. Estuar Coast Shelf Sci 97:91-103

Erga SR, Lie GC, Aarø LH, Frette Ø, Hamre B (2015) Migratory behaviour of Skeletonema grethae (Bacillariophyceae) in stratified waters. Diatom Res 30:13-25

Estrada M, Berdalet E (1997) Phytoplankton in a turbulent world. Sci Mar 61:125-140

- Fan C, Glibert PM, Burkholder JM (2003) Characterization of the affinity for nitrogen, uptake kinetics, and environ- mental relationships for Prorocentrum minimum in natural blooms and laboratory cultures. Harmful Algae 2: 283-299

Fauchot J, Levasseur M, Roy S (2005) Daytime and nighttime vertical migrations of Alexandrium tamarense in the St. Lawrence estuary (Canada). Mar Ecol Prog Ser 296: 241-250

Figueroa FL, Niell FX, Figueiras FG, Villarino ML (1998) Diel migration of phytoplankton and spectral light field in the Ría de Vigo (NW Spain). Mar Biol 130:491-499

Fraga F, Pérez FF, Figueiras FG, Ríos AF (1992) Stoichiometric variations of N, P, C and $\mathrm{O}_{2}$ during a Gymnodinium catenatum red tide and their interpretation. Mar Ecol Prog Ser 87:123-134

> Frette Ø, Erga SR, Hamre B, Aure J, Stamnes JJ (2004) Seasonal variability in inherent optical properties in a western Norwegian fjord. Sarsia 89:276-291

- Garces E, Delgado M, Masó M, Camp J (1999) In situ growth rate and distribution of the ichthyotoxic dinoflagellate Gyrodinium corsicum Paulmier in an estuarine embayment (Alfacs Bay, NW Mediterranean Sea). J Plankton Res 21:1977-1991

> Gentien P, Lunven M, Lazure P, Youenou A, Crassous MP (2007) Motility and autotoxicity in Karenia mikimotoi (Dinophyceae). Philos Trans R Soc Lond B Biol Sci 362: 1937-1946

> Ghorai S, Hill NA (2005) Penetrative phototactic bioconvection. Phys Fluids 17:074101

Grindley JR, Nel EA (1970) Red water and mussel poisoning at Elands Bay, December 1966. Fish Bull (S Afr) 6:36-55

Häder DP, Richter P, Lebert M (2006) Signal transduction in gravisensing of flagellates. Signal Transduct 6:422-431

> Hales B, Hebert D, Marra J (2009) Turbulent supply of nutrients to phytoplankton at the New England shelf break front. J Geophys Res 114:C05010, doi:10.1029/2008JC005011

> Han MS, Kim YP, Cattolico RA (2002) Heterosigma akashiwo (Raphidophyceae) resting cell formation in batch culture: strain identity versus physiological response. J Phycol 38:304-317

- Hasle GR (1950) Phototactic vertical migration in marine dinoflagellates. Oikos 2:162-175

> Heaney SI, Eppley RW (1981) Light, temperature and nitrogen interacting factors affecting diel vertical migrations of dinoflagellates in culture. J Plankton Res 3:331-344

> Heaney SI, Talling JF (1980) Dynamic aspects of dinoflagellate distribution patterns in a small productive lake. J Ecol 68:75-94

Hershberger PK, Rensel JE, Matter AL, Taub FB (1997) Vertical distribution of the chloromonad flagellate Heterosigma carterae in columns: implications for bloom development. Can J Fish Aquat Sci 54:2228-2234

Hutchinson GE (1953) The concept of pattern in ecology. Proc Acad Nat Sci Phila 105:1-11

> Jeong HJ, Yoo YD, Kim JS, Seong KA, Kang NS, Kim TH (2010) Growth, feeding and ecological roles of the mixotrophic and heterotrophic dinoflagellates in marine planktonic food webs. Ocean Sci J 45:65-91

Jephson T, Carlsson P (2009) Species- and stratificationdependent diel vertical migration behaviour of three dinoflagellate species in a laboratory study. J Plankton Res 31:1353-1362

> Jephson T, Fagerberg T, Carlsson P (2011) Dependency of dinoflagellate vertical migration on salinity stratification. Aquat Microb Ecol 63:255-264 
Johannsen CJ (2004) Studies on growth and toxicity of Protoceratium reticulatum (Dinophyceae) based on different nitrogen sources and temperature regimes - including analysis of intraspecific variation based on ITS sequences. MSc thesis, University of Copenhagen

John EH, Flynn KJ (2000) Growth dynamics and toxicity of Alexandrium fundyense (Dinophyceae): the effect of changing N:P supply ratios on internal toxin and nutrient levels. Eur J Phycol 35:11-23

> Johns DG, Edwards M, Richardson A, Spicer JI (2003) Increased blooms of a dinoflagellate in the NW Atlantic. Mar Ecol Prog Ser 265:283-287

Kamykowski D (1995) Trajectories of autotrophic marine dinoflagellates. J Phycol 31:200-208

Kamykowski D, Yamazaki H (1997) A study of metabolisminfluenced orientation in the diel vertical migration of marine dinoflagellates. Limnol Oceanogr 42:1189-1202

Kamykowski D, Zentara DSJ (1977) Diurnal vertical migration of motile phytoplankton through temperaturegradients. Limnol Oceanogr 22:148-151

Kamykowski D, Reed RE, Kirkpatrick GJ (1992) Comparison of sinking velocity, swimming velocity, rotation and path characteristics among six marine dinoflagellate species. Mar Biol 113:319-328

Kamykowski D, Milligan EJ, Reed RE (1998) Relationships between geotaxis/phototaxis and diel vertical migration in autotrophic dinoflagellates. J Plankton Res 20: 1781-1796

Kamykowski D, Milligan EJ, Reed RE, Liu W (1999) Geotaxis/phototaxis and biochemical patterns in Heterocapsa (= Cachonina) illdefina (Dinophyceae) during diel vertical migrations. J Phycol 35:1397-1403

Karimi A, Ardekani AM (2013) Gyrotactic bioconvection at pycnoclines. J Fluid Mech 733:245-267

Kessler JO (1985) Hydrodynamic focusing of motile algal cells. Nature 313:218-220

Koizumi Y, Uchida T, Honjo T (1996) Diurnal vertical migration of Gymnodinium mikimotoi during a red tide in Hoketsu Bay, Japan. J Plankton Res 18:289-294

Levandowsky M, Kaneta PJ (1987) Behaviour in dinoflagellates. In: Taylor FJR (ed) The biology of dinoflagellates. Blackwell Scientific, Oxford, p 360-397

> Lewis NI, Xu W, Jericho SK, Kreuzer HJ, Jericho MH, Cembella AD (2006) Swimming speed of three species of Alexandrium (Dinophyceae) as determined by digital in-line holography. Phycologia 45:61-70

> Lieberman OS, Shilo M, Rijn J (1994) The physiological ecology of a freshwater dinoflagellate bloom population: vertical migration, nitrogen limitation, and nutrient uptake kinetics. J Phycol 30:964-971

- MacIntyre JG, Cullen JJ, Cembella AD (1997) Vertical migration, nutrition and toxicity in the dinoflagellate Alexandrium tamarense. Mar Ecol Prog Ser 148:201-216

MacIsaac JJ (1978) Diel cycles of inorganic nitrogen uptake in a natural phytoplankton population dominated by Gonyaulax polyedra. Limnol Oceanogr 23:1-9

MacKenzie L, Holland P, McNabb P, Beuzenberg V, Selwood A, Suzuki T (2002) Complex toxin profiles in phytoplankton and greenshell mussels (Perna canaliculus), revealed by LC-MS/MS analysis. Toxicon 40: 1321-1330

Manfrin C, De Moro G, Torboli V, Venier P, Pallavicini A, Gerdol M (2012) Physiological and molecular responses of bivalves to toxic dinoflagellates. Invertebr Surviv J 9: 184-199
McKay L, Kamykowski D, Milligan E, Schaeffer B, Sinclair G (2006) Comparison of swimming speed and photophysiological responses to different external conditions among three Karenia brevis strains. Harmful Algae 5:623-636

> Mitchell JG, Okubo A, Fuhrman JA (1990) Gyrotaxis as a new mechanism for generating spatial heterogeneity and migration in microplankton. Limnol Oceanogr 35: 123-130

> Montechiaro F, Giordano M (2010) Compositional homeostasis of the dinoflagellate Protoceratium reticulatum grown at three different $\mathrm{pCO}_{2}$. J Plant Physiol 167: 110-113

> Olsson P, Granéli E (1991) Observations on diurnal vertical migration and phased cell division for three coexisting marine dinoflagellates. J Plankton Res 13:1313-1324

Paasche E, Erga SR (1988) Phosphorus and nitrogen limitation of phytoplankton in the inner Oslofjord (Norway). Sarsia 73:229-243

Park JG, Jeong MK, Lee JA, Cho KJ, Kwon OS (2001) Diurnal vertical migration of a harmful dinoflagellate, Cochlodinium polykrikoides (Dinophyceae), during a red tide in coastal waters of Namhae Island, Korea. Phycologia 40:292-297

Parsons TR, Maita Y, Lalli CM (1992) A manual of chemical and biological methods for seawater analysis. Pergamon Press, New York, NY

> Passow U (1991) Vertical migration of Gonyaulax catenata and Mesodinium rubrum. Mar Biol 110:455-463

Pedley TJ, Kessler JO (1992) Bioconvection. Sci Prog 16: 105-123

Persson A, Smith BC (2013) Cell density-dependent swimming patterns of Alexandrium fundyense early stationary phase cells. Aquat Microb Ecol 68:251-258

Pingree RD, Pugh PR, Holligan PM, Forster GR (1975) Summer phytoplankton blooms and red tides along tidal fronts in the approaches to the English Channel. Nature 258:672-677

Pitcher GC, Boyd AJ, Horstman DA, Mitchell-Innes BA (1998) Subsurface dinoflagellate populations, frontal blooms and the formation of red tide in the southern Benguela upwelling system. Mar Ecol Prog Ser 172: 253-264

Raine R, McMahon T (1998) Physical dynamics on the continental shelf off southwestern Ireland and their influence on coastal phytoplankton blooms. Cont Shelf Res 18: 883-914

Rasmussen J, Richardson K (1989) Response of Gonyaulax tamarensis to the presence of a pycnocline in an artificial water column. J Plankton Res 11:747-762

$>$ Ratti S, Giordano M, Morse D (2007) $\mathrm{CO}_{2}$-concentrating mechanisms of the potentially toxic dinoflagellate Protoceratium reticulatum (Dinophyceae, Gonyaulacales). J Phycol 43:693-701

Raven JA, Richardson K (1984) Dinophyte flagella: a costbenefit analysis. New Phytol 98:259-276

> Röder K, Hantzsche FM, Gebühr C, Miene C and others (2012) Effects of salinity, temperature and nutrients on growth, cellular characteristics and yessotoxin production of Protoceratium reticulatum. Harmful Algae 15: $59-70$

> Satake M, MacKenzie L, Yasumoto T (1997) Identification of Protoceratium reticulatum as the biogenic origin of yessotoxin. Nat Toxins 5:164-167

Shikata T, Sakamoto S, Onitsuka G, Aoki K, Yamaguichi M (2014) Effects of salinity on diel vertical migration behav- 
ior in two red-tide algae, Chattonella antiqua and Karenia mikimotoi. Plankton Benthos Res 9:42-50

Smayda TJ (1997) Harmful algal blooms: their ecophysiology and general relevance to phytoplankton blooms in the sea. Limnol Oceanogr 42:1137-1153

Smayda TJ (2002) Turbulence, watermass stratification and harmful algal blooms: an alternative view and frontal zones as 'pelagic seed banks'. Harmful Algae 1:95-112

Smayda TJ, Reynolds C (2001) Community assembly in marine phytoplankton: application of recent models to harmful dinoflagellate blooms. J Plankton Res 23:447-461

Sullivan JM, Swift E (2003) Effects of small-scale turbulence on net growth rate and size of ten species of marine dinoflagellates. J Phycol 39:83-94

Tardio M, Spitale D, Cantonati M (2005) Vertical migration of a dinoflagellate in a column-shaped enclosure in Lake Tovel (Adamello-Brenta Natural Park, Italian Alps). Verh Int Verein Limnol 29:143-146

Thomas WH, Gibson CH (1990) Effects of small-scale turbulence on microalgae. J Appl Phycol 2:71-77

Tobin ED, Grünbaum D, Patterson J, Cattolico RA (2013) Behavioral and physiological changes during benthicpelagic transition in the harmful alga, Heterosigma akashiwo: potential for rapid bloom formation. PLoS ONE 8: e76663

Editorial responsibility: Katherine Richardson, Copenhagen, Denmark
Tyler MA, Seliger HH (1981) Selection for a red tide organism: physiological responses to the physical environment. Limnol Oceanogr 26:310-324

Villarino ML, Figueiras FG, Jones KJ, Alvarez-Salgado XA, Richard J, Edwards A (1995) Evidence of in situ diel vertical migration of a red-tide microplankton species in Ría de Vigo (NW Spain). Mar Biol 123:607-617

- Vincent RV, Hill NA (1996) Bioconvection in a suspension of phototactic algae. J Fluid Mech 327:343-371

> Wager H (1911) On the effect of gravity upon the movements and aggregation of Euglena viridis, Ehrb., and other micro-organisms. Philos Trans R Soc Lond B Biol Sci 201:333-390

Weise AM, Levasseur M, Saucier FJ, Senneville S and others (2002) The link between precipitation, river runoff, and blooms of the toxic dinoflagellate Alexandrium tamarense in the St. Lawrence. Can J Fish Aquat Sci 59: 464-473

Whittington J, Sherman B, Green D, Oliver RL (2000) Growth of Ceratium hirundinella in a subtrophical Australian reservoir: the role of vertical migration. J Plankton Res 22:1025-1045

- Zhan C, Sardina G, Lushi E, Brandt L (2014) Accumulation of motile elongated micro-organisms in turbulence. J Fluid Mech 739:22-36

Submitted: April 27, 2015; Accepted: September 17, 2015 Proofs received from author(s): November 6, 2015 